\title{
Arboreal Diversity of the Atlantic Forest of Southern Brazil: From the Beach Ridges to the Paraná River
}

\author{
Maurício Bergamini Scheer ${ }^{1}$ and Christopher Thomas Blum² \\ ${ }^{1}$ Research and Development Assistance, Sanepar \\ 2Sociedade Chauá \\ Brazil
}

\section{Introduction}

The Atlantic Forest (a hotspot for conservation) used to be the second largest tropical moist forest of South America (Oliveira-Filho \& Fontes, 2000). It originally covered 20\% (around 1.5 million $\mathrm{km}^{2}$ ) of the Brazilian territory and occupied highly heterogeneous environmental conditions (Ribeiro et al., 2009). Nowadays, however, the Atlantic Forest covers less than $1 \%$ of the country or $7.5 \%$ of remnants (Myers et al., 2000). When intermediate secondary forests and small fragments (< 100 ha) are included, this contribution increases, ranging from 11.4 to $16 \%$ (Ribeiro et al. 2009). The Atlantic Forest still comprises 20000 plant species, 8000 being endemic (Myers, 2000).

For instance, in the 1950s, $40 \%$ of the Atlantic Forest still covered almost all the state of Paraná in Southern Brazil (Fundação SOS Mata Atlântica et al., 1998). During the following three decades, habitats that took thousands of years to evolve continued to be destroyed. What remains today covers an area 9.5 times smaller $(10.58 \%)$ than the original area (Fundação SOS Mata Atlântica \& INPE, 2010). This coincided with a period when the government aimed at an "economic development". However, this erroneous decision caused an irreparable loss of ecosystem functions (e.g. amount and quality of water, soil, carbon stocks, biodiversity, etc). Once more, immediate "development" led to the loss of a valuable ecosystem that had potential to bring true and sustainable development. The respect for the natural dynamics of ecosystems and species evolution is rarely presented in environmental discussions. Therefore it is timely to study biodiversity and to promote its management and restoration.

This chapter aims at discussing tree diversity of different formations of the Atlantic Forest in Southern Brazil, using data from phytosociological studies carried out in the state of Paraná. This study attempts to assess the following questions:

What ecosystems are understudied in terms of phytosociological surveys? Are the tree species richness and diversity of the different formations of these Atlantic Forests sufficiently known? What are the tree species richness and the diversity when considering only individuals found in phytosociological surveys? What species are the most abundant in each ecosystem evaluated? What are the differences and similarities among these formations? 


\section{Data analysis}

Besides presenting a brief literature review, this study compiles abundance data and updated floristic information from the most representative tree phytosociological studies of the Atlantic Forest formations in the state of Paraná, Southern Brazil. The data were obtained from scientific papers, doctoral thesis, master dissertations and from our own surveys performed for at least 10 years in the region (Table 1). The floristic information from 39 studies encompassing 58 forest sites was included in the present study.

There was a difficulty in finding studies with same inclusion criteria (same diameter at breast height - DBH) for different formations. The minimum DBH value available in the original dataset ranged from 3.1 to $10.0 \mathrm{~cm}$. This range was therefore considered in the present study. Additionally, the different sample sizes were not standardized among surveys.

The altitudes of the sites range from 5 to $1750 \mathrm{~m}$ a.s.l. The most distant sites (separated by $590 \mathrm{~km}$ ) are located in the following geographic coordinates: $25^{\circ} 23^{\prime} \mathrm{S}$; $48^{\circ} 13^{\prime} \mathrm{W}$, near the Atlantic Ocean and $22^{\circ} 43^{\prime}$ S; $53^{\circ} 18^{\prime}$ W, near the Upper Paraná River (Figure 1).

Sites in early and middle sucessional stages, as well as undetermined taxa and exotic species were not included. Taxa identified only to the family or genus level were grouped according to taxonomic hierarchy. For example: the Myrtaceae group included many undetermined taxa of this family, and the Lonchocarpus group comprised undetermined species of this genus. For the richness estimation, each taxonomic group of undetermined taxa was considered as a unique species. The data underwent a detailed review to check all accepted species names and synonymy according to the "Species List of the Brazilian Flora" (Forzza et al., 2010). The compilation of the surveys on forest structure comprised 29 hectares of sampled area and 36627 measured individuals. The diversity indexes were calculated according to Magurran (1988). Canonical correspondence analyses (CCA) processed by the program CANOCO 4.5 (Ter Braak \& Smilauer, 2002) were used to assess the relationship between abundance of the tree species of 58 sites comprising nine Atlantic Forest formations, and geo-climatic variables. The matrix with abundances per forest site includes 631 species. The geo-climatic matrix includes the following variables: distance from the ocean, annual temperature, altitude and annual rainfall. Data not presented in the original studies were obtained from climatic maps of IAPAR (Caviglione et al., 2000). Major approximations of mean annual temperatures (decrease of $0.54{ }^{\circ} \mathrm{C}$ for every $100 \mathrm{~m}$ of increased altitude) were used following recommendations in Roderjan \& Grodski (1999). The Brazilian official vegetation classification (Veloso et al., 1991; IBGE, 1992) was used to group the sites into each Atlantic Forest formation (see below).

\section{Atlantic Forest Biome, environmental and vegetational features}

The Atlantic Forest in the state of Paraná has three distinct types of forest ecosystems: the Dense Rainforest (Atlantic “Ombrophilous" Dense Forest), the Araucaria Rainforest (Mixed "Ombrophilous" Forest) and the Semideciduous Seasonal Forest (IBGE, 1992). Each one of these forests also comprises distinct formations and associated or ingrown ecosystems, resulting from geomorphological and climatological features (Figure 1). The five main categories of formations (IBGE, 1992) were included, namely: Lowland (Coastal Plain Forest), Alluvial (Floodplain Forest), Submontane and Montane (both can be also considered Lower Montane), and Upper Montane. The Dense Rainforest presents all of these categories, whilst the Araucaria Rainforest and the Semideciduous Seasonal Forest Comprise mainly the Alluvial and Montane and the Alluvial and Submontane formations, respectively. 
Arboreal Diversity of the Atlantic Forest

\begin{tabular}{|c|c|c|c|c|c|}
\hline $\mathbf{N}$ & $\begin{array}{c}\text { Forest } \\
\text { formation }\end{array}$ & Municipality & $\begin{array}{c}\text { Location } \\
\text { (site) }\end{array}$ & $\begin{array}{c}\text { Alt. } \\
\text { (m a.s.1.) }\end{array}$ & Reference \\
\hline 1 & Lowland DRF & Guaraqueçaba & Ilha do Superagui & 12 & Jaster (1995) \\
\hline 2 & Lowland DRF & Guaratuba & Guaratuba & 10 & Galvão et al. (2002) \\
\hline 3 & Lowland DRF & Matinhos & Matinhos & 10 & Galvão et al. (2002) \\
\hline 4 & Lowland DRF & Paranáguá & Ilha do Mel & 5 & Menezes Silva (1990) \\
\hline 5 & Alluvial DRF & Guaraqueçaba & Itaqui Reserve/site1 & 20 & Zacarias (2008) \\
\hline 6 & Alluvial DRF & Guaraqueçaba & Itaqui Reserve/site2 & 20 & Zacarias (2008) \\
\hline 7 & Submontane DRF & Antonina & Cachoeira Reserve & 350 & Liebsch et al. (2007) \\
\hline 8 & Submontane DRF & Guaraqueçaba & Morro do Quitumbe & 200 & Athayde (1997) \\
\hline 9 & Submontane DRF & Guaraqueçaba & Morro do Superagui & $20-170$ & Jaster (1995) \\
\hline 10 & Submontane DRF & Guaratuba & Rio Cubatãozinho & 400 & Guapyassu (1994) \\
\hline 11 & Submontane DRF & Morretes & Morretes & 485 & Silva (1994) \\
\hline 12 & Submontane DRF & Morretes & Serra da Prata/site1 & $400-600$ & Blum (2006) \\
\hline 13 & Montane DRF & Guaratuba & Morro dos Perdidos & 800 & Blum et al. (2001) \\
\hline 14 & Montane DRF & Morretes & Serra da Prata/site2 & $800-1100$ & Blum (2006) \\
\hline 15 & Montane DRF & Piraquara & Mananciais da Serra & 1030 & Reginato \& Goldenberg (2007) \\
\hline 16 & Montane DRF & Quatro Barras & Morro Anhangava/site2 & 1150 & Roderjan (1994) \\
\hline 17 & Montane DRF & São José dos Pinhais & Guaricana/site1 & $500-700$ & Schorn (1992) \\
\hline 18 & Montane DRF & São José dos Pinhais & Guaricana/site2 & $500-700$ & Schorn (1992) \\
\hline 19 & Upper Montane DRF & Morretes & Pico Marumbi & 1385 & Rocha (1999) \\
\hline 20 & Upper Montane DRF & Quatro Barras & Morro Anhangava/site3 & 1300 & Portes et al. (2001) \\
\hline 21 & Upper Montane DRF & Quatro Barras & Morro Anhangava/site1 & 1350 & Roderjan (1994) \\
\hline 22 & Upper Montane DRF & Morretes & Serra da Prata/site3 & 1400 & Scheer et al. (in press a) \\
\hline 23 & Upper Montane DRF & Antonina & Serra do Ibitiraquire & 1700 & Scheer et al. (in press a) \\
\hline 24 & Upper Montane DRF & Morretes & Serra da Igreja & 1300 & Scheer et al. (in press a) \\
\hline 25 & Upper Montane DRF & Guaraqueçaba & Serra Gigante & 950 & Scheer et al. (in press a) \\
\hline 26 & Upper Montane DRF & Morretes & Morro Mãe Catira & 1300 & Koehler (2001) \\
\hline 27 & Upper Montane DRF & Tijucas do Sul & Morro Araçatuba & 1400 & Koehler (2001) \\
\hline 28 & Upper Montane DRF & São José dos Pinhais & Serra do Salto & 1300 & Koehler (2001) \\
\hline 29 & Upper Montane DRF & Morretes & Morro Vigia & 1300 & Koehler (2001) \\
\hline 30 & Alluvial ARF & Araucária & Distr.General Lúcio/site1 & 897 & Pasdiora (2003) \\
\hline 31 & Alluvial ARF & Araucária & Distr.General Lúcio/site2 & 897 & Pasdiora (2003) \\
\hline 32 & Alluvial ARF & Araucária & Rio Barigui & 875 & Barddal et al. (2004) \\
\hline 33 & Alluvial ARF & Pinhais & Pinhais/site2 & 850 & Seger et al. (2005) \\
\hline 34 & Alluvial ARF & São José dos Pinhais & Rio Miringuava/site1 & 880 & Jaster et al. (2002) \\
\hline 35 & Montane ARF & Curitiba & Barigui Park & 900 & Kozera et al. (2006) \\
\hline 36 & Montane ARF & Curitiba & Capão do Tigre & 900 & Rondon Neto et al. (2002) \\
\hline 37 & Montane ARF & General Carneiro & Fazenda Pizzato & 990 & Watzlawick et al. (2005) \\
\hline 38 & Montane ARF & Guarapuava & Fazenda 3 Capões/site1 & 950 & Cordeiro (2010) \\
\hline 39 & Montane ARF & Guarapuava & Fazenda 3 Capões/site2 & 950 & Cordeiro (2010) \\
\hline 40 & Montane ARF & Guarapuava & Fazenda 3 Capões/site3 & 950 & Cordeiro (2010) \\
\hline 41 & Montane ARF & Guarapuava & Fazenda 3 Capões/site4 & 950 & Cordeiro (2010) \\
\hline 42 & Montane ARF & Guarapuava & Araucárias Park & 1070 & Cordeiro \& Rodrigues (2007) \\
\hline 43 & Montane ARF & Jaguariaíva & Paredão da Santa & 1195 & Blum (ongoing study) \\
\hline 44 & Montane ARF & Pinhais & Pinhais/site1 & 850 & Seger et al. (2005) \\
\hline 45 & Montane ARF & São João do Triunfo & São João do Triunfo & 780 & Durigan (1999) \\
\hline 46 & Montane ARF & São José dos Pinhais & Rio Miringuava/site2 & 910 & Jaster et al. (2002) \\
\hline 47 & Montane ARF & Tijucas do Sul & Tijucas do Sul & 850 & Geraldi et al. (2005) \\
\hline 48 & Montane ARF & Tijucas do Sul & Fazenda Bührer & 850 & Geraldi et al. (2005) \\
\hline 49 & Alluvial SSF & Diamante do Norte & Caiuá Ecol.Station/site1 & 250 & Borghi et al. (2004) \\
\hline 50 & Alluvial SSF & Diamante do Norte & Caiuá Ecol.Station/site2 & 250 & Costa Filho et al. (2006) \\
\hline 51 & Alluvial SSF & Porto Rico & Alto Paraná & 240 & Campos et al. (2000) \\
\hline 52 & Alluvial SSF & Londrina & Ribeirão dos Apertados & 500 & Bianchini et al. (2003) \\
\hline 53 & Submontane SSF & Astorga & Ribeirão Aurora & 550 & Veiga et al. (2003) \\
\hline 54 & Submontane SSF & Diamante do Norte & Caiuá Ecol.Station/site3 & 280 & Del Quiqui et al. (2007) \\
\hline 55 & Submontane SSF & Londrina & Mata dos Godoy Park & 500 & Soares-Silva et al. (1998) \\
\hline 56 & Submontane SSF & Sapopema & Fazenda Bom Sucesso & 780 & Silva et al. (1995) \\
\hline 57 & Submontane SSF & Tomazina & Rio das Cinzas & 500 & Blum et al. (2003) \\
\hline 58 & Submontane SSF & Umuarama & Estrada Boiadeira & 450 & Blum \& Petean (2008) \\
\hline
\end{tabular}

Table 1. List of the analyzed fores sites in Atlantic Forest formations in the state of Paraná, Brazil. (N - site number used in this study; DRF - Dense Rainforest; ARF - Araucaria Rainforest; SSF - Semidecidual Seasonal Forest). 


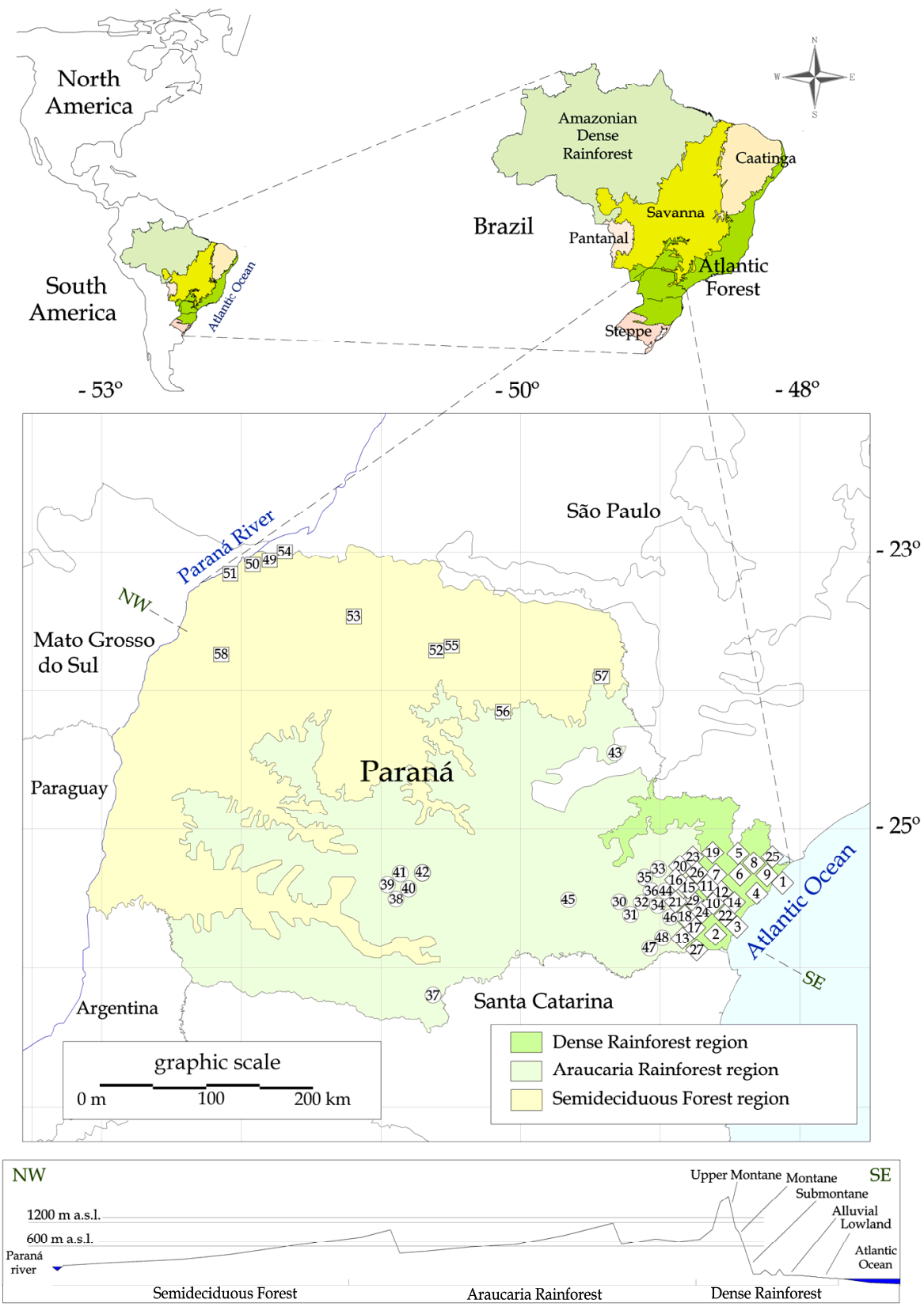

Adapted from: MMA (2011) and Roderjan et al. (2002).

Fig. 1. Location of the 58 sites in the Atlantic Forest types in the state of Paraná, Southern Brazil. Numbers are related to sites presented in Table 1. 


\subsection{Dense Rainforest}

The Dense Rainforest, or Atlantic Forest sensu stricto (Oliveira-Filho \& Fontes, 2000), is characterized by the dominance of large trees (25-30 m height) associated with many other biological forms, mainly epiphytes and woody lianas, that gives it its tropical appearance (Klein, 1979). Evergreen trees dominate the dense canopy (Veloso et al., 1991; IBGE, 1992).

Different plant communities of this forest type are found from the beach ridges near the Atlantic Ocean to the upper montane ridges of the Serra do Mar (Sea Mountain Range) and its western slopes towards the ecotone with Araucaria Rainforest (Figure 1). The altitudinal gradient ranges from 1 to $1887 \mathrm{~m}$ a.s.l., resulting in this region in a decrease of $0.54{ }^{\circ} \mathrm{C}$ for every $100 \mathrm{~m}$ increase in altitude (Roderjan \& Grodski, 1999). While the coastal plain formations are in soils derived from Cenozoic (mainly Quaternary) marine sediments, alkali granites, embedded in high-grade metamorphic terrains, form the mineral soil horizons of the upper portions of the landscape. According to Mineropar (2001), intrusive igneous rocks from Serra do Mar were originated nearly 550 million years ago in the Upper Proterozoic to Cambrian. Faults from the Brasiliano (or Pan African) Cycle (events of the end of the late Proterozoic) and the Ponta Grossa Arch, cut the landscape in the NE-SW and NW-SE axes, respectively. Therefore, the soils of the Dense Rainforest have a high variety in parent material, genesis, depth, horizons, layers, structure, texture and organic matter.

The climate of the lower portions of the Dense Rainforest gradient, up to the transition between the Submontane and Montane formations, 600 - $800 \mathrm{~m}$ a.s.l. (Blum, 2010), can be classified as Cfa, or meso-thermic, according to the Köppen classification system. Daily mean annual temperature is $21^{\circ} \mathrm{C}$, the mean temperature in the coldest month is about $16^{\circ} \mathrm{C}$ and, in the warmest month is higher than $22^{\circ} \mathrm{C}$, with hot and wet summers (December-March), and a no-pronounced dry season. Maack (2002) considered the region as having a transitional tropical climate (Af). The climate of upper portions, above $700 \mathrm{~m}$ a.s.l., is classified as $\mathrm{Cfb}$ (humid subtropical, meso-thermic, with cool summers, frequent frosts and no pronounced dry season). The mean temperature of the coldest month (July) in the region is less than $16{ }^{\circ} \mathrm{C}$ (reaching $12.5^{\circ} \mathrm{C}$ ) and of the warmest month (February) is less than $22{ }^{\circ} \mathrm{C}\left(20.5{ }^{\circ} \mathrm{C}\right)$. Measurements in the coastal region exceed $2000 \mathrm{~mm}$ of rain per year, and on the slopes of the mountains these values reach $3500 \mathrm{~mm}$ of rain per year (Caviglione et al., 2000; Maack, 2002).

As a result of the high environmental variety the Dense Rainforest is the most heterogeneous, complex and rich forest ecosystem of Southern Brazil (Leite \& Klein, 1990). A compiled list of the tree flora of the Dense Rainforest of Southern Brazil, using data of the botanical collection of the Barbosa Rodrigues Herbaria, revealed 708 species. More than $50 \%$ of those species occur exclusively in this type of Atlantic Forest (Leite \& Klein, 1990).

Dense Rainforest communities in the advanced stages of succession cover an area of 3937.5 $\mathrm{km}^{2}$ or $51,5 \%$ of the original distribution area as interpreted from satellite images from 1999 (Pires et al., 2005).

Forward we present the five cattegories of the Atlantic Rainforest.

\subsubsection{Lowland formation}

In South Brazil, the Lowland formation (Coastal Plain Forest) is restricted to Quaternary coastal plains growing on tsites near to sea level to about $20 \mathrm{~m}$ a.s.1.. Poorly developed soils and the high susceptibility to flooding during the rainiest periods are remarkable factors that led to its typical floristic and structural composition (Leite \& Klein, 1990; Veloso et al., 1991; IBGE, 1992; Roderjan et al., 2002; Pires et al., 2005). 
This formation presents a continuous canopy (about 20-25 m height) and two physiognomies can be distinguished. Calophyllum brasiliense trees dominate the canopy of areas with soils subject to waterlogging (Histosols, Spodosols and Entisols). This species is generally associated with Tabebuia cassinoides, Tapirira guianensis, Ficus luschnatiana, Ilex pseudobuxus, Clusia criuva and Pouteria beaurepairei. In better-drained lands, non-hydromorphic Entisols (Quartzipsamments/Arenosols) and Spodosols support higher diversity. There are common in the canopy Tapirira guianensis, Ocotea pulchella, Ficus organensis, Manilkara subcericea, Pera glabrata, Alchornea triplinervia, Andira anthelmia, Ilex theezans, Ternstroemia brasiliensis, besides many Myrtaceae such as Psidium cattleianum and Myrcia multiflora (Leite \& Klein, 1990; Silva, 1990; Jaster, 1995; Jaster, 2002; Roderjan et al., 2002; Pires et al., 2005).

\subsubsection{Alluvial formation}

The Alluvial Dense Rainforest grows in Fluvisols and Gleysols in alluvial plains influenced by mountain range sediments carried by rivers (Roderjan et al., 2002).

The canopy is usually 20-25 m tall and some expressive species of this formation are Pseudobombax grandiflorum, Alchornea triplinervia, Ficus organensis, Andira anthelmia and Syagrus romanzoffiana. Inga sessilis, Coussapoa microcarpa, Psidium cattleianum, Ocotea pulchella, Myrcia insularis and Marlierea tomentosa are also important in these communities (Roderjan et al., 2002; Pires et al., 2005; Zacarias, 2008).

\subsubsection{Submontane formation}

This ecosystem comprises the lower portions of slopes of the mountain ranges and the Ribeira River Valley. According to IBGE (1992), this formation occurs between 30 and $400 \mathrm{~m}$ a.s.l.. However, Roderjan et al. (2002) adapted the upper limit of the Submontane formation to $600 \mathrm{~m}$ a.s.l., considering the regional scale. Results of a survey performed by Blum \& Roderjan (2007) agree well with this limit. The Submontane Atlantic Rainforest generally occurs on Argisols, Oxisols and Cambisols, mainly in colluvial fans (Roderjan et al., 2002).

The dense canopy varies between 25 and $30 \mathrm{~m}$ in height and is characterized by high tree diversity and richness. Virola bicuhyba, Sloanea guianensis, Aspidosperma pyricollum, Cedrela fissilis, Cariniana estrellensis, Pseudopiptadenia warmingii and Schyzolobium parahyba are frequent in the canopy. Bathysa australis, Pausandra morisiana, Euterpe edulis, Geonoma gamiova and Psychotria nuda are common in the dominated strata (Leite \& Klein, 1990; Maack, 2002; Roderjan et al., 2002; Pires et al., 2005; Blum, 2006).

This formation presents the highest floristic diversity of Southern Brazil due to the combination of factors like soils with good physical support and nutritional capacity, higher temperatures and well distributed rainfalls (Leite \& Klein, 1990; Roderjan et al., 2002). These features also promote the development of dense and large-sized arboreal communities, associated with terrestrial and epiphytic strata, extremely rich and abundant (Blum, 2010).

\subsubsection{Montane formation}

The forest communities distributed over the intermediate slopes of the mountain ranges at elevations above the Submontane limits are classified as Montane formations. According to Roderjan et al. (2002) and Blum (2006), in the state of Paraná these communities are situated between 600 and $1200 \mathrm{~m}$ a.s.1..

It is noteworthy that the upper limit is also variable depending on specific soil and climate and, in many cases, the Upper Montane formation can already occur below $1200 \mathrm{~m}$ a.s.l. (Pires et al., 2005). Floristic differences are observable in relation to the lower level, but 
structurally and physiognomic, the Montane and Submontane formations are similar (Roderjan et al., 2002; Pires et al., 2005). Cambisols (with no textural gradient) and Entisols are very common in the Montane belt (Schorn, 1992; Roderjan, 1994, Blum, 2006).

The main environmental factors that affect the differentiation between the Montane and Submontane formations (Lower Montane Forests) are the climate, the topography and the soils. In the Montane Atlantic Forest it can occur occasional frosts, which are extremely limiting for many typical species of Submontane formation, that are subject to milder climate. It should be noted that the geomorphological differences result in distinct pedologies. The Montane terrains are steep and dissected while the Submontane sites are usually understated (Roderjan et al., 2002; Pires et al., 2005; Blum, 2006; 2010).

The canopy of the Montane Dense Rainforest is regular, varying about 20-25 m height. Several species of Lauraceae dominate in the upper strata, especially Ocotea catharinensis, Ocotea odorifera, Ocotea bicolor and Cryptocarya aschersoniana. Aspidosperma pyricollum, Pouteria torta, Cabralea canjerana, Sloanea lasiocoma, Guapira opositta, Ilex paraguariensis and Guatteria australis are also relevant. The lower strata are characterized by Myrtaceae, Rubiaceae and Monimiaceae families. Ferns (tree ferns) such as Cyathea phalerata and another species of Cyatheaceae are common in the understory (IBGE, 1992; Roderjan, 1994; Blum et al., 2001; Roderjan et al., 2002; Pires et al., 2005; Blum, 2006).

\subsubsection{Upper Montane formation}

In the state of Paraná, faults belonging to the Brasiliano (or Pan African) Cycle and the Ponta Grossa Arch currently confine the Upper Montane Rainforests (or Cloud Forests), allowing such vegetation to reach areas close to the main tops of the Sea Mountain Range (Scheer et al., in press b). This formation generally occurs from $1200 \mathrm{~m}$ a.s.l (Roderjan et al., 2002), even though it can be found at $900 \mathrm{~m}$ a.s.l., in small isolated mountains due to geomorphological conditions and the "Massenerhebung effect" (Grubb, 1971). In larger mountains, such as the Paraná Peak, the typical Upper Montane Rainforest ranges from 1400 to $1850 \mathrm{~m}$ a.s.l.., interspersed with high altitude grasslands. The changes in vegetation from forests to grasslands are abrupt and include ecotonal areas with "dwarf forests" or shrubby physiognomy with species of both formations across a gradient of a few meters $(2-5 \mathrm{~m})$.

Although typical Upper Montane Forests are composed by simplified tree associations, 346 vascular plant species have been detected in four mountain ranges (Scheer \& Mocochinski, 2009). Small-sized trees ranging from 3 to $7 \mathrm{~m}$ tall, are subject to more restrict environmental conditions, such as low temperatures, strong winds and constant and heavy cloudiness, intense light radiation and shallow soils with low fertility and substantial histic horizons (Histosols and Leptosols). Ilex microdonta, Siphoneugena reitzii, Myrceugenia seriatoramosa, Citronella paniculata, Weinmannia humilis, Ocotea porosa, Podocarpus sellowii and Drimys brasiliensis are typical species in such areas (Leite \& Klein, 1990; Roderjan, 1994, Koehler et al., 2002; Roderjan et al., 2002; Pires et al., 2005; Scheer, 2010; Scheer et al., in press a).

\subsection{Araucaria Rainforest}

Also called "Mixed Ombrophilous Forest" (IBGE, 1992), this forest physiognomy is characterized by merging elements from two distinct flora origins: the Tropical AfroBrazilian and the Temperate Austro-Brazilian (Veloso et al., 1991). Classified as a Subtropical Forest, this ecosystem occurs mainly in the First and Second Plateaus of Paraná (mainly in the Center and the South of the state) at altitudes generally varying between 800 and $1000 \mathrm{~m}$ a.s.l. (Figure 1). In this region, temperatures are relatively low and frosts are common. In many locations, these formations share the landscape with natural grasslands. 
According to Köppen System, the climate of the Araucaria Rainforest region is $\mathrm{Cfb}$, with annual average temperatures between 16 and $18{ }^{\circ} \mathrm{C}$ and average annual rainfall generally between 1400 and $1600 \mathrm{~mm}$ (Caviglione et al., 2000).

This forest formation shows structural variations related to environmental diversification, varying from dense formations with trees of ca. 25 to $35 \mathrm{~m}$ tall, to stunted formations consisting of variable density of trees and shrubs, associated with terrestrial ferns and bamboos (Leite \& Klein, 1990). According to Maack (2002), Araucaria angustifolia, commonly known as the "Brazilian pine" or "Paraná pine" is the dominant tree of this region, distinguishing this landscape.

A compiled list of the Araucaria Rainforest tree flora of Southern Brazil, using data of the botanical collection of the Barbosa Rodrigues Herbaria, revealed 352 species. Almost $50 \%$ of those species occur exclusively in this type of Atlantic Forest (Leite \& Klein, 1990).

Castella \& Britez (2004) analyzed satellite images from 1998 and concluded that Araucaria Rainforest communities at intermediate or advanced succession stages still covered 13420.6 $\mathrm{km}^{2}$ of the state of Paraná, representing about $16.2 \%$ of the original cover (Castella \& Britez, 2004). However, primary remnants are much less representative.

Two formations are presented in this section: Alluvial and Montane Araucaria Rainforests.

\subsubsection{Alluvial formation}

The Alluvial Araucaria Rainforest is associated mainly with the Montane formation and is easily distinguished by its typical physiognomy. This is a riparian forest that always occupies alluvial lands adjacent to watercourses (IBGE, 1992; Roderjan et al., 2002).

The physiognomy is structurally characterized by a high density of medium and small individuals, with the canopy ranging between 10 and $20 \mathrm{~m}$ in height. Communities can present different degrees of development. In the fairly homogeneous associations, subject to soils with considerable hydromorphy, such as some Fluvisols and Gleysols, Sebastiania commersoniana is the most relevant species. In more developed associations Vitex megapotamica, Schinus terebinthifolius, Allophylus edulis, Luehea divaricata, Symplocos uniflora, Blepharocalyx salicifolius, Myrrhinium atropurpureum, Myrciaria tenella and Daphnopsis racemosa are present. Even Araucaria angustifolia can be observed where lower hydromorphy allows its growth (Leite \& Klein, 1990; Roderjan et al., 2002; Barddal, 2002; Pires et al., 2005).

\subsubsection{Montane formation}

According to IBGE (1992), the altitudinal range of the Montane Araucaria Rainforest occurrence is between 400 and $1000 \mathrm{~m}$ a.s.l.. However, some authors, such as Leite \& Klein (1990) and Roderjan et al. (2002), rightly argue that typical communities occur at altitudes higher than $800 \mathrm{~m}$ a.s.l. Below this altitudinal belt there is the beginning of the transition between the Montane Araucaria Rainforest and the Dense Atlantic Rainforest (on the east) or the Semideciduous Seasonal Forest (on the west).

The typical physiognomy is marked by the dominance of Araucaria angustifolia, standing out over a continuous canopy that reaches on average $25-30 \mathrm{~m}$ height. The continuous strata is characterized by Ocotea porosa, Nectandra lanceolata, Matayba elaeagnoides, Casearia decandra, Podocarpus lambertii, Cinnamodendron dinisii, Sloanea lasiocoma, Campomanesia xanthocarpa, Cedrela fissilis, Nectandra grandiflora, Jacaranda puberula, Drimys brasiliensis, Ilex paraguariensis and Lithraea brasiliensis. Species of Myrtaceae and Monimiaceae prevail in the dominated strata. Ferns, especially Dicksonia sellowiana, are also common (Leite \& Klein, 1990; Durigan, 1999; Roderjan et al., 2002; Rondon Neto et al., 2002; Cordeiro \& Rodrigues, 2007). 


\subsection{Semideciduous Seasonal Forest}

The Semideciduous Seasonal Forest region in the the state of Paraná occurs mainly in the Third Plateau (almost the entire North and West of the state) in altitudes generally between 200 and $600 \mathrm{~m}$ a.s.l. (Roderjan et al., 2002).

According to the Köppen system, the climate can be classified as $\mathrm{Cfa}$, or meso-thermic, wet. Daily mean temperatures in the coldest month are under $18{ }^{\circ} \mathrm{C}$ and the mean temperature of the warmest month is over $22^{\circ} \mathrm{C}$ (Maack, 2002). However, in this ecosystem the year can be divided into two distinct seasons: one tropical with intense summer rainfalls and short dry periods, and another subtropical with low winter temperatures and scarce precipitation. During this unfavorable cold and dry period, between 20 and $50 \%$ of the canopy trees are deciduous (Veloso et al., 1991; IBGE, 1992). In very specific locations this forest has as ingrown ecosystem the Savanna (Cerrado), which reaches its austral limit in this specified region, covering otherwise a major part of Brazil's Mid-West (Figure 1).

The Semideciduous Seasonal Forest shows succinct variations ranging from the evergreen to deciduous trees, which reach heights close to 30-40 m without forming a continuous superior canopy. This feature allows a great deal of sunlight to reach the forest ground, turning possible the development of a vigorous lower stratum (Silva \& Soares Silva, 2000). There are also shrubs, lianas and epiphytes, although in lower abundance and richness compared to rainforests (Leite et al., 1986; Lamprecht, 1990; Leite \& Klein, 1990; Roderjan et al., 2002).

A compiled list of the tree flora of the Semideciduous Seasonal Forest of Southern Brazil, using data of the botanical collection of the Barbosa Rodrigues Herbaria, presents at least 213 tree species (Leite \& Klein, 1990). Silva \& Soares Silva (2000), found 206 arboreal species in Godoy State Park.

Satellite images taken in 1998, indicate that $4174.7 \mathrm{~km}^{2}$ of Semideciduous Seasonal Forest communities at intermediate or advanced stages of succession covered only $5.4 \%$ of the original area of distribution in that year (SEMA, 2002). Some forests of the northern region were reduced to less than $1 \%$ in Maringá and $0.8 \%$ in Assaí municipalities (IPARDES, 1986). Forward are presented the characterizations for the Alluvial and Submontane formations of this forest type.

\subsubsection{Alluvial formation}

This formation is distributed over riverine floodplains and some islands in the Paraná river, and also around some of its tributaries. The Alluvial formation occurs predominantly in soils with considerable hydromorphy, such as some Fluvisols, Entisols (Quartzipsamments) and Gleysols (Roderjan et al., 2002).

The Alluvial Semideciduous Seasonal Forest is characterized by a canopy about 15 to $20 \mathrm{~m}$ height and lower floristic diversity. Among the main species are Cecropia pachystachya, Triplaris americana, Calophyllum brasiliense, Gallesia integrifolia and Chrysophyllum gonocarpum. Sebastiania commersoniana, Anadenanthera colubrina, Acrocomia aculeata and Inga uruguensis are also common (Leite et al. 1986; IBGE, 1992, Roderjan et al., 2002; SEMA, 2002; Costa Filho et al., 2006).

\subsubsection{Submontane formation}

In the state of Paraná, this formation can be found under $600 \mathrm{~m}$ a.s.l.. The Submontane Semideciduous Seasonal Forest occurs in soils of different lithologies (sandstone and igneous extrusive rocks) that result in Oxisols, Ultisols, Regosols (Psamments), Inceptisols, Leptosols and Arenosols (Roderjan et al., 2002). Depending on the lithology, different textures and fertility levels can be found in these soils. 
The emergent irregular canopy can reach around 35-40 m height. In the upper stratum are common Aspidosperma polyneuron, Handroanthus heptaphyllus, Gallesia integrifolia, Balfourodendron riedelianum, Peltophorum dubium, Astronium graveolens, Diatenopteryx sorbifolia, Parapitadenia rigida, Cariniana estrellensis, Cedrela fissilis, Albizia hasslerii, Lonchocarpus guilleminianus, Machaerium stipitatum, Holocalyx balansae, Rauvolfia sellowii, and Nectandra megapotamica, among others. The dominated strata are characterized by Guarea macrophylla, Actinostemon concolor, Metrodorea nigra, Sorocea bomplandii and Pilocarpus pennatifolius (Hueck, 1972; Leite et al., 1986; Leite \& Klein, 1990; Maack, 2002; Roderjan et al., 2002; SEMA, 2002).

\section{The studied Atlantic Forest formations}

\subsection{Analysis of the sampled sites in the Atlantic Forests}

Among the 58 sites, comprising 29 ha of plots and 36627 sampled individuals, selected from 39 studies, the Dense Rainforest has the highest number of sampled sites (29 out of a total of 58 ) and the highest number of tree individuals found (Table 2). This great amount of data available is due to the high number of Upper Montane Dense Rainforest sampled sites, which present relatively many areas with primary and well preserved vegetation. In spite of the relatively smaller sampled area, small-sized trees present in high abundance make up for a high number of individuals found.

On the other hand, the Alluvial formation of the Dense Rainforest is the least sampled one (Table 2). The lack of phytosociological studies conducted in this formation may be related to its actual small cover area (representing only $0.89 \%$ of the remnants of Dense Rain Forest) (Pires et al., 2005), and also to its level of degradation, which make the search for typical and representative remnants difficult. According to this data, the studied area is almost six times smaller than the area of the neighbor Lowland formation. Therefore, this understudied vegetation needs more studies.

The low number of studied sites in the Semideciduous Seasonal Forest in the state of Paraná is also remarkable, especially when the great covering area (Figure 1) and the considerable latitudinal extension $\left(22^{\circ} 30^{\prime}-26^{\circ} 30^{\prime} \mathrm{S}\right)$ of this ecosystem are considered. The lack of studies is related to the advanced stage of degradation of this forest type. In a few decades this ecosystem was reduced to scarce and fragmented remnants, generally in bad conservation conditions. We did not find phytosociological surveys in the Southwestern region of the state of Paraná, where the Semideciduous Forest is also found (Figure 1). Moreover, forest structure studies are not available even in the most representative remnant of the Submontane Semideciduous Forest of Southern Brazil, located in the Iguaçu National Park, a protected area of approximately $1852.6 \mathrm{~km}^{2}$. This fact points out to the urgency of knowing better this important ecosystem and its resources.

Besides the similar sampled areas shown by the three Atlantic Forest types (Table 2), and highest number of studied sites for the Dense Rainforest, the sum of the 10 sites of the Semideciduous Forest comprises the largest sampled area (11.8 ha). The two most extensively sampled formations are the Montane Araucaria Rainforest and the Submontane Semideciduous Forest. However, these sampling areas are very small compared to the sampling area of other surveys in different ecosystems. As an example, a single study in the Amazonian Dense Forest, could easily cover an area of 20 ha (Pitman et al., 2002; Laurance et al., 2010).

\subsection{Alfa diversity}

In the 58 selected phytosociological surveys, 700 species, 256 genera and 83 families were sampled (Table 2). Of the total number of species, 10 taxa represent groups with 
undetermined species at the family level and 58 taxa represent groups with undetermined species at the genus level. It is important to mention that the Atlantic Forest is habitat for many other tree species that were not found due to the criterion of inclusion, or due do the area needed to sample, that neither checklists can cover completely.

\begin{tabular}{|c|c|c|c|c|c|c|c|c|c|c|c|}
\hline Biome & $\begin{array}{c}\text { Atlantic } \\
\text { Forest } \\
\text { types }\end{array}$ & $\begin{array}{c}\text { Atlantic } \\
\text { Forest } \\
\text { formations }\end{array}$ & $\begin{array}{c}\text { Number } \\
\text { of sites }\end{array}$ & $\begin{array}{l}\text { Sampled } \\
\text { area (ha) }\end{array}$ & $\begin{array}{c}\text { Number of } \\
\text { measured } \\
\text { individuals }\end{array}$ & $\begin{array}{c}\text { Number } \\
\text { of } \\
\text { species }\end{array}$ & $\begin{array}{c}\text { Number } \\
\text { of } \\
\text { genera }\end{array}$ & $\begin{array}{c}\text { Number } \\
\text { of } \\
\text { families }\end{array}$ & $\begin{array}{l}\text { Shannon- } \\
\text { Wiener } \\
\text { Diversity } \\
\text { Index }\end{array}$ & $\begin{array}{l}\text { - Simpson } \\
\text { Diversity } \\
\text { Index } \\
\text { 1-D }\end{array}$ & Evenness \\
\hline \multirow{13}{*}{ 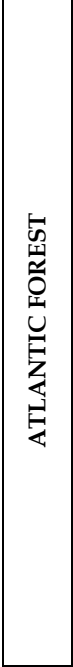 } & \multirow{6}{*}{ 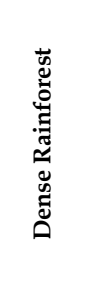 } & & 29 & 9.01 & 14165 & 469 & 174 & 72 & 5.11 & 0.99 & - \\
\hline & & Alluvial & 2 & 0.32 & 766 & 78 & 59 & 32 & 3.38 & 0.94 & 0.77 \\
\hline & & Lowland & 4 & 1.86 & 2808 & 148 & 87 & 49 & 3.93 & 0.96 & 0.79 \\
\hline & & Submontane & 6 & 2.38 & 3251 & 265 & 132 & 57 & 4.61 & 0.98 & 0.83 \\
\hline & & Montane & 6 & 3.48 & 3140 & 210 & 101 & 52 & 4.64 & 0.98 & 0.87 \\
\hline & & Upper Montane & 11 & 0.97 & 4200 & 88 & 45 & 30 & 3.20 & 0.93 & 0.71 \\
\hline & \multirow{3}{*}{ 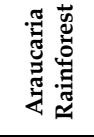 } & & 19 & 8.30 & 9196 & 220 & 101 & 51 & 4.29 & 0.97 & - \\
\hline & & Aluvial & 5 & 0.81 & 1792 & 79 & 54 & 33 & 2.48 & 0.74 & 0.57 \\
\hline & & Montane & 14 & 7.49 & 7404 & 211 & 99 & 50 & 4.38 & 0.98 & 0.82 \\
\hline & \multirow{3}{*}{ 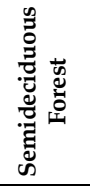 } & & 10 & 11.80 & 13265 & 282 & 154 & 60 & 4.64 & 0.99 & - \\
\hline & & Alluvial & 4 & 4.34 & 5354 & 157 & 107 & 43 & 4.26 & 0.98 & 0.84 \\
\hline & & Submontane & 6 & 7.46 & 7911 & 252 & 140 & 56 & 4.46 & 0.98 & 0.81 \\
\hline & \multicolumn{2}{|c|}{ ATLANTIC FOREST } & 58 & 29.11 & 36627 & 700 & 256 & 83 & 5.53 & 0.99 & - \\
\hline
\end{tabular}

Table 2. Richness and other diversity parameters of the analyzed Atlantic Forest formations in the state of Paraná, Southern Brazil.

Among the Atlantic Forest types analyzed in this study, the Dense Rainforest is the richest in tree species (469). These species are distributed in 174 genera and 72 families. This tropical forest presents the highest tree diversity according to the Shannon-Wiener index, being its Montane and Submontane formations the most diverse (Table 2; Figure 3). Even though the analysis shows the highest diversity value in the Montane formation, according to many studies, the Submontane formation shows a tendency of being the most diverse (Guapyassú, 1994; Roderjan, 1994; Jaster, 1995; Athayde, 1997; Blum, 2006).

Tabarelli \& Mantovani (1999) compiled phytosociological studies on the Dense Rainforest in Southeastern Brazil, which comprised 432 species measured in 2.3 ha and considered 2640 trees measured through the quarter-plot method. According to these authors the richness of these forests are low when compared to other Neotropical Forests of South America. However, more studies considering similar conditions (e.g. larger plots - 1 ha - with homogeneous sites) are needed to corroborate these results.

However, some diversity indexes such as Eveness presented for the Atlantic Forest types can be influenced by the disproportionate sampling among their formations.

According to Table 2, the Araucaria Rainforest presents less than half of the Dense Rainforest tree species richness (220), in part due to its lower environmental heterogeneity 
and altitudinal range. In addition, the colder climate in the Araucaria Rainforest region probably restricts the occurrence of a substantial number of species.

The Semideciduous Seasonal Forest shows intermediate values of species richness (282) and diversity when compared with the two types of Rainforests. (Table 2; Figure 3).

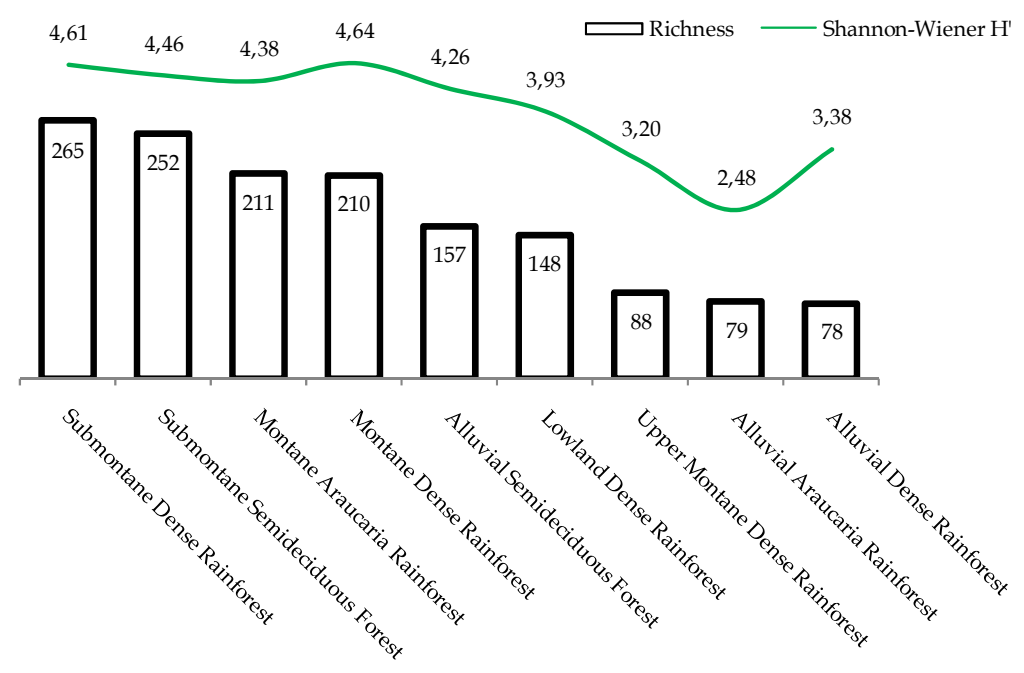

Fig. 3. Tree richness and Shannon-Wiener diversity indexes of the Atlantic Forest formations in the state of Paraná, Southern Brazil.

The higher richness when compared with the Araucaria Rainforest is due to some distinct environmental conditions, such as lower altitude, which result in higher temperatures. On the other hand, the restriction imposed by the seasonal climate, especially by the unfavorable dry season, prevents the Seasonal Forest to reach values of species richness similar to those observed in the Dense Rainforest (i.e. 66\% higher). A lower difference (31\%) in this parameter between these two types of forest was observed by Oliveira Filho \& Fontes (2000) in floristic surveys in Southeastern Brazil.

The Submontane formations present the highest richness of tree species, followed by the Montane formations (Figure 3). The Lowland, Upper Montane and Alluvial formations present lower richness. From the data available, the Alluvial Dense Rainforest has the lowest number of species. However, this is certainly related to the lack of inventories in this type of forest. Due its proximity and environmental similarity with the coastal Lowland formation, it is probable that the real values of tree species richness of both forests are similar.

Therefore, among the Atlantic Forest formations, the Alluvial Araucaria Rainforest can be considered the least rich in tree species. This is due to two important environmental factors: the milder climate, with frequent frosts; and the hydromorphic feature of its soils, with high susceptibility to flooding during the rainiest periods.

According to Table 3, Myrtaceae, Fabaceae and Lauraceae are the families with the highest tree species richness of the Atlantic Forest, making up to $40 \%$ of the measured Rainforest species and $35 \%$ of the Semideciduous Seasonal Forest species.

Myrtaceae presents the highest number of tree species in the two Rainforests, reaching 112 species in the Dense Rainforest, while Fabaceae is the richest family of the Semideciduous 
Forest. Some tree families, such as Fabaceae, Moraceae, Sapotaceae and Meliaceae, show a tendency of preferring warmer environments. On the other hand, Aquifoliaceae, Asteraceae and Myrsinaceae present comparatively high floristic expression in the Rainforest environments. In addition, Melastomataceae presents high species richness only in the Dense Rainforest. According to Gentry (1995) and Oliveira-Filho et al. (2000), with increasing altitude there is a decrease in Fabaceae richness and an increase in Aquifoliaceae and Asteraceae richness.

At the genus level, Eugenia is the richest in the tropical forests (mainly in the Dense Rainforest), even though the Araucaria Rainforest (subtropical) presents many species of this taxon. Oliveira-Filho et al. (2000) observed the same tendency in an extensive survey on floristic differentiation patterns among Atlantic Forests in Southeastern Brazil. The richness of Eugenia is relatively higher in slope rain forests, and its relative position is reversed with Myrcia in lowland (including alluvial) and plateau (Araucaria Rainforest) formations. Marlierea has a considerable number of species in Lowland and Submontane formations of the Dense Rainforest, whilst Myrceugenia has many species in Upper Montane and Montane formations of both rainforests (Table 4).

Ocotea is among the three genera with the highest number of tree species in the three Atlantic Forest types in the state of Paraná. Ilex and Myrceugenia have a considerable number of species in the two rainforests, whilst Trichilia and Cordia have many species in the Semideciduous Forest (Tables 3 and 4).

\begin{tabular}{|c|c|c|c|c|c|c|c|c|c|c|c|}
\hline \multicolumn{4}{|c|}{ Dense Rainforest $(S=469 ; N=29)$} & \multicolumn{4}{|c|}{ Araucaria Rainforest $(\mathrm{S}=220 ; \mathrm{N}=19)$} & \multicolumn{4}{|c|}{ Semideciduous Forest $(S=282 ; N=10)$} \\
\hline Family & $S$ & Genus & $\mathrm{S}$ & Family & $\mathrm{S}$ & Genus & $\mathrm{S}$ & Family & $\mathrm{S}$ & Genus & $\mathrm{S}$ \\
\hline Myrtaceae & 112 & Eugenia & 39 & Myrtaceae & 49 & Myrcia & 14 & Fabaceae & 47 & Eugenia & 13 \\
\hline Lauraceae & 39 & Myrcia & 25 & Lauraceae & 23 & Ocotea & 11 & Myrtaceae & 32 & Nectandra & 8 \\
\hline Fabaceae & 35 & Ocotea & 18 & Fabaceae & 18 & Eugenia & 10 & Lauraceae & 19 & Ocotea & 8 \\
\hline Rubiaceae & 24 & Miconia & 12 & Asteraceae & 10 & Myrceugenia & 8 & Meliaceae & 13 & Trichilia & 8 \\
\hline Melastomataceae & 21 & Ilex & 11 & Rubiaceae & 10 & Ilex & 6 & Rubiaceae & 11 & Cordia & 7 \\
\hline Moraceae & 12 & Myrceugenia & 11 & Salicaceae & 8 & Myrsine & 6 & Solanaceae & 11 & Solanum & 7 \\
\hline Sapotaceae & 12 & Calyptranthes & 10 & Solanaceae & 8 & Solanum & 6 & Salicaceae & 10 & Inga & 6 \\
\hline Aquifoliaceae & 11 & Inga & 9 & Aquifoliaceae & 6 & Symplocos & 6 & Euphorbiaceae & 9 & Myrcia & 6 \\
\hline Euphorbiaceae & 11 & Nectandra & 9 & Myrsinaceae & 6 & Casearia & 5 & Rutaceae & 9 & Casearia & 5 \\
\hline Asteraceae & 9 & Marlierea & 8 & Sapindaceae & 6 & Maytenus & 5 & Boraginaceae & 7 & Ficus & 5 \\
\hline Myrsinaceae & 9 & Myrsine & 8 & Symplocaceae & 6 & Allophylus & 4 & Moraceae & 7 & Lonchocarpus & 5 \\
\hline Annonaceae & 8 & Symplocos & 8 & Annonaceae & 5 & Lonchocarpus & 4 & Sapotaceae & 7 & Machaerium & 5 \\
\hline Meliaceae & 8 & Coccoloba & 7 & Celastraceae & 5 & Machaerium & 4 & Annonaceae & 6 & Pouteria & 5 \\
\hline Salicaceae & 8 & Psychotria & 7 & Euphorbiaceae & 4 & Nectandra & 4 & Malvaceae & 6 & Sloanea & 4 \\
\hline Sapindaceae & 8 & Ficus & 6 & Rutaceae & 4 & Piptocarpha & 4 & Sapindaceae & 6 & Zanthoxylum & 4 \\
\hline
\end{tabular}

Table 3. The 15 best represented families and genera measured in the three Atlantic Forest types of the state of Paraná, Southern Brazil. $\mathrm{S}=$ number of species, $\mathrm{N}=$ number of sites.

The most abundant species found in phytosociological studies in the Atlantic Forest formations in the state of Paraná are given in Table 5. Except for the Alluvial, the sampling for all the other formations can be considered very representative of what can be found in these forests. This compilation obtained data for at least 2800 individuals and four sites for each formation, whereas phytosociological studies for the Semideciduous Seasonal forest in the Southwest of the state of Paraná cannot be found. 


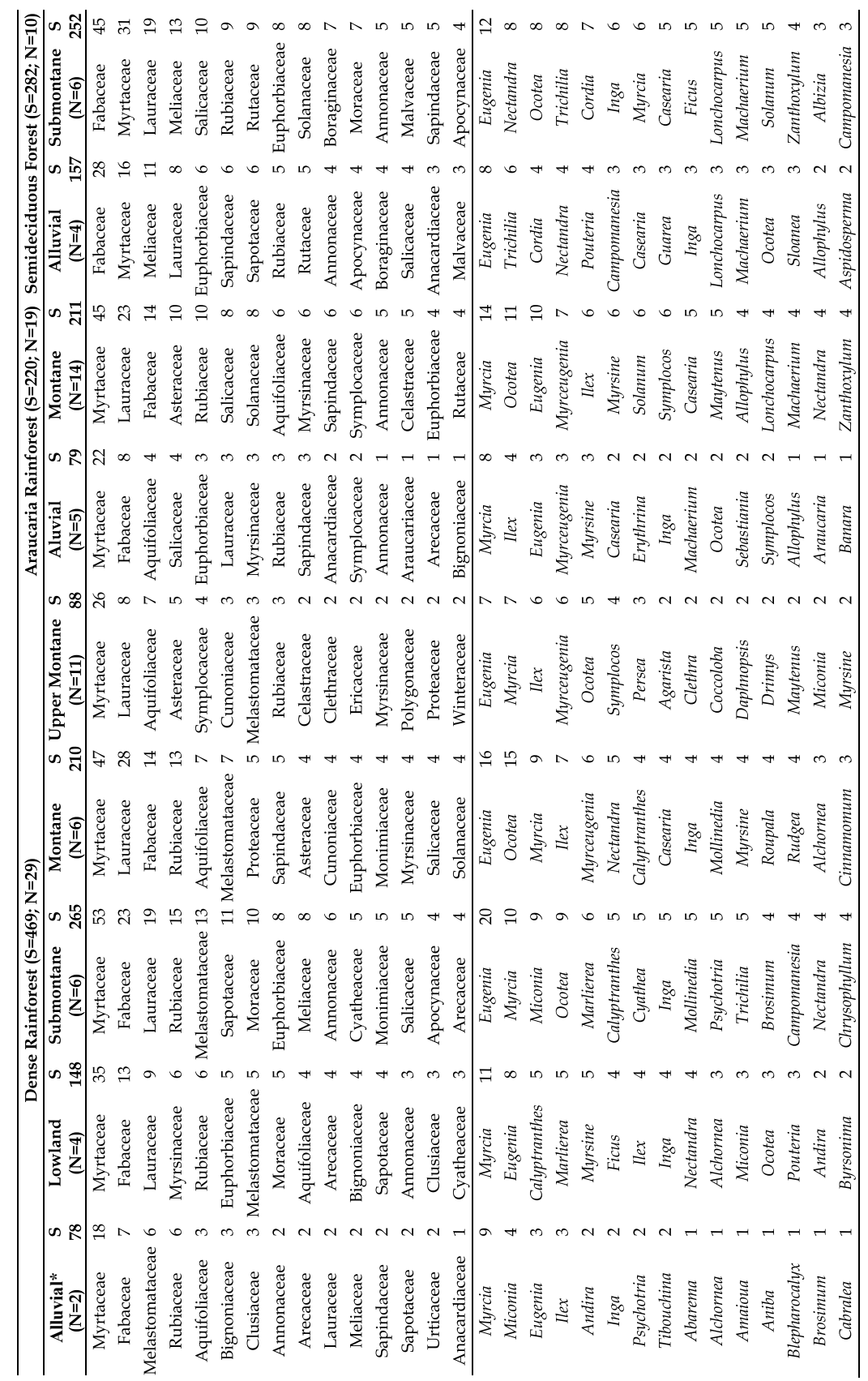

Table 4. The 15 best represented families and genera measured in the nine Atlantic Forest formations of the state of Paraná, Southern Brazil. $\mathrm{S}=$ number of species, $\mathrm{N}=$ number of sites. *Data from Zacarias (2008). 


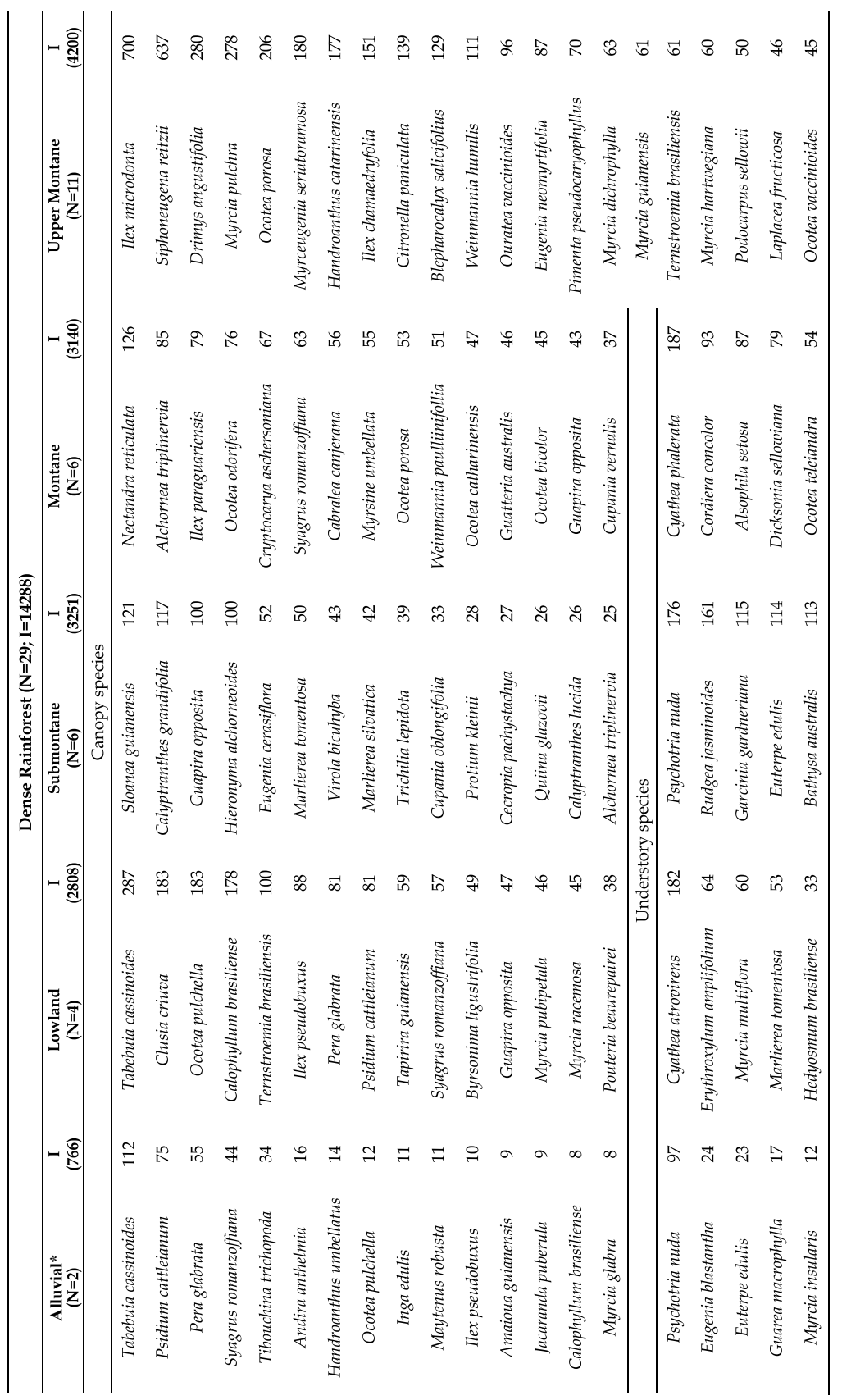

Table 5. Species with the highest number of individuals measured for each formation of Atlantic Forest in the state of Paraná, Southern Brazil. $\mathrm{I}=$ number of sampled individuals, $\mathrm{N}=$ number of sites. *Data from Zacarias (2008). 


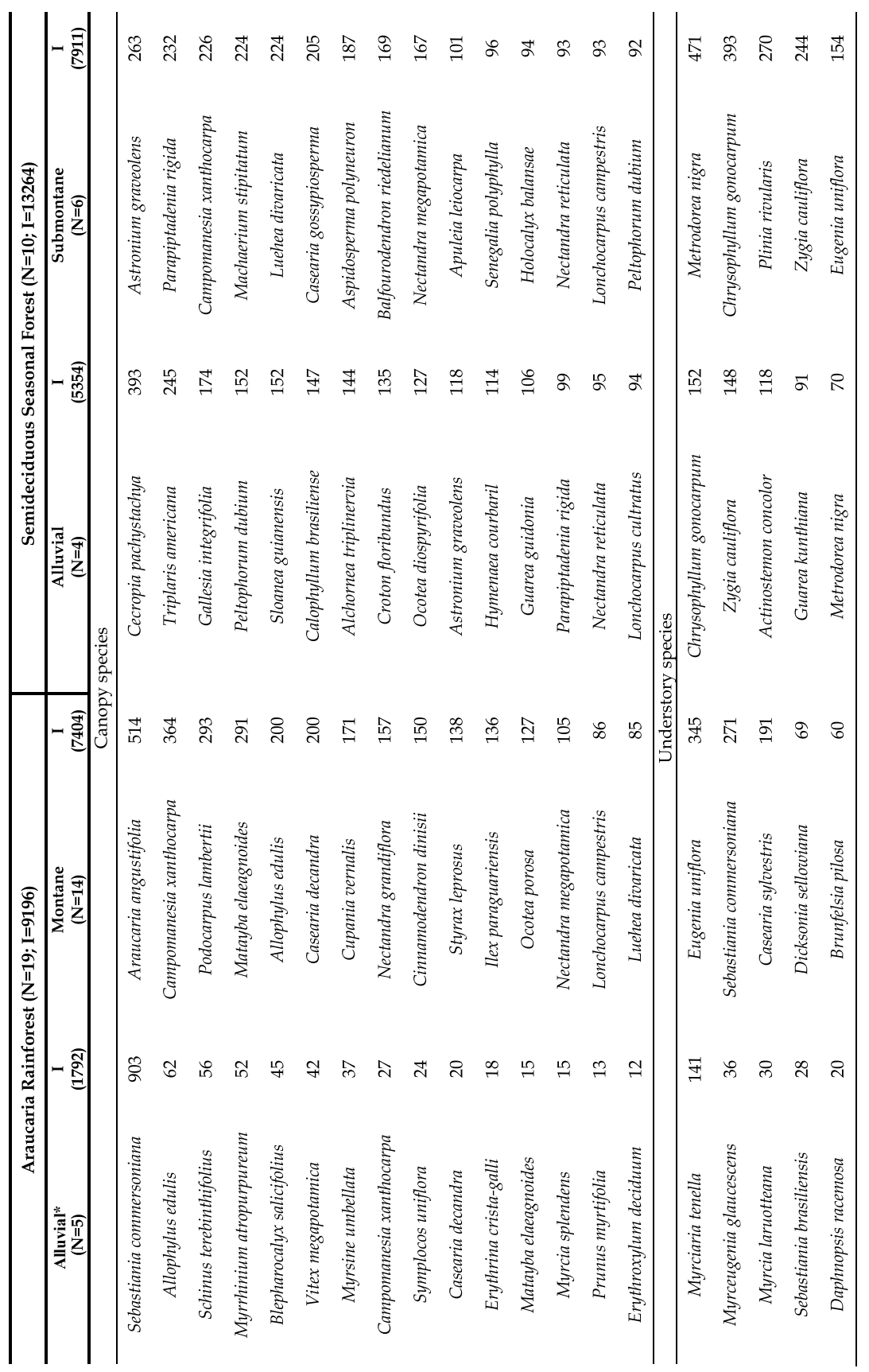

Table 5. (Continued) 


\section{Beta diversity of Atlantic Forest formations}

According to the Venn diagrams (Figure 4), the two Rainforest types share at least 99 tree species, most of them very common in the Montane formations of both forest types, like Cinnamodendrum dinisii, Ocotea porosa, Drimys brasiliensis and Ocotea odorifera. The surveys carried out in the Dense Rainforest shared 94 species with the Semideciduous Forest, which in turn shared 88 species with the Araucaria Rainforest. At least 50 arboreal species $(8 \%$ of the species measured) occur in the three Atlantic Forest types, such as Campomanesia xanthocarpa, Casearia sylvestris, Alchornea triplinervia, Nectandra megapotamica, Sloanea guianensis, Cupania vernalis, Casearia decandra, Syagrus romanzoffiana, Blepharocalyx salicifolius, Myrsine umbellata, Ocotea pulchella and Ilex paraguariensis, among the most abundant.

A total of 272 species were found exclusively in the Dense Rainforest, e.g. Tibouchina trichopoda, Andira anthelmia, Handroanthus umbellatus, Tabebuia cassinoides, Clusia criuva, Pera glabrata, Ternstroemia brasiliensis, Virola bicuhyba, Marlierea tomentosa, Cupania oblongifolia, Protium kleinii, Quiina glazovii, Aspidosperma pyriccolum, Myrcia freyreissiana, Siphoneugena reitzii, Drimys angustifolia and Handroanthus catarinensis.

At least 51 tree species were found only in Araucaria Rainforest surveys, such as Podocarpus lambertii, Nectandra grandiflora, Lithraea brasiliensis, Guettarda uruguensis, Curitiba prismatica, Symplocos celastrinea, Myrrhinium atropurpureum, Myrcianthes pungens, Ocotea nutans, Erythroxylum deciduum, Cinnamomum amoenum and Zanthoxylum kleinii.

Among the 127 species found only in the Semideciduous Seasonal Forest (Figure 4), the most abundant are Chrysophyllum gonocarpum, Metrodorea nigra, Astronium graveolens, Parapiptadenia rigida, Plinia rivularis, Casearia gossypiosperma, Triplaris americana, Balfourodendron riedelianum, Peltophorum dubium, Holocalyx balansae, Aspidosperma polyneuron and Gallesia integrifolia.

The dendrogram using Sorensen's similarity coefficients for tree species (Figure 5) shows two major distinct groups. The first one comprises the five Dense Rainforest formations, and the second comprises the Araucaria Rainforest and the Semideciduous Seasonal Forest, reinforcing the data given in Venn diagram (Figure 4). These two types of Atlantic Forest

ATLANTIC FORESTS
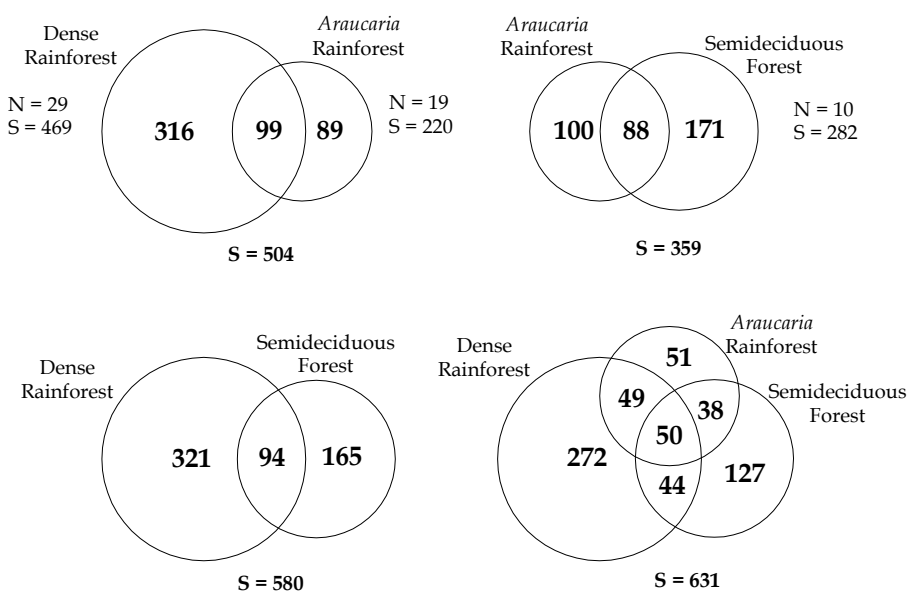

Fig. 4. Venn diagrams presenting the number of measured tree species shared in the 58 sites of the three types of Atlantic Forest in the state of Paraná, Southern Brazil. 
share $24.5 \%$ of the total species. The two Rainforests share $19.6 \%$ of the species and the Semideciduous Seasonal Forest share $16.2 \%$ of the species with the Dense Rainforest. These values differ from those found by Oliveira-Filho \& Fontes (2000), in which Dense Rainforest and Semideciduous Forest of Southeastern Brazil shared a high proportion of tree species in their checklists: $50 \%$ and $66 \%$ respectively.

The comparatively high floristic similarity within the Southeastern region than in the Southern region, can be related to the absence of Araucaria Rainforests between these two tropical forests further north.

In the group of the Dense Rainforest, "slope forests" were separated from the "coastal and alluvial plain" forests (Figure 5). The second main group divided the Araucaria Rainforest and the Semideciduous Seasonal Forest.

Pair wise comparisons of the Sorensen's similarity coefficients show values ranging from 0.09 between the Alluvial Semideciduous Forest and the Upper Montane Dense Rainforests to 0.61 between the two formations of the Semideciduous Forest.

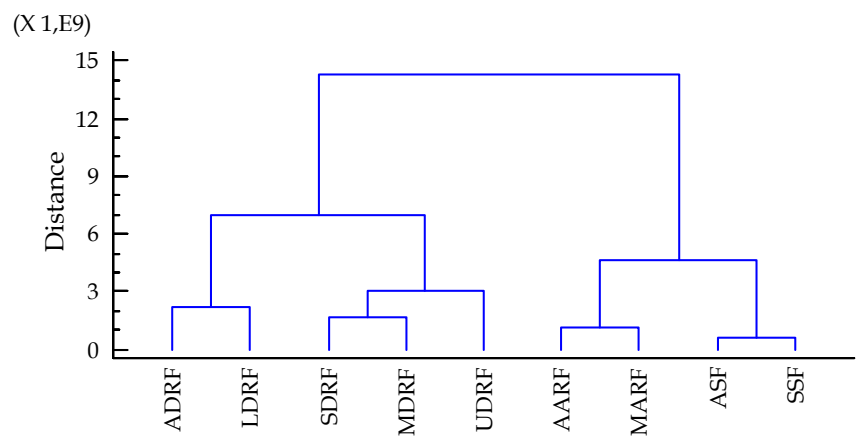

Fig. 5. Dendrogram showing the similarity between tree species measured in nine main formations of the Atlantic Forest of the state of Paraná, Southern Brazil. The cluster analysis was carried out using Sorensen's similarity coefficients, squared euclidean distances and the Ward's method of agglomeration (DRF - Dense Rainforest; ARF - Araucaria Rainforest; SF - Seasonal Forest; A - Alluvial; L - Lowland; S - Submontane; M - Montane; U - Upper Montane).

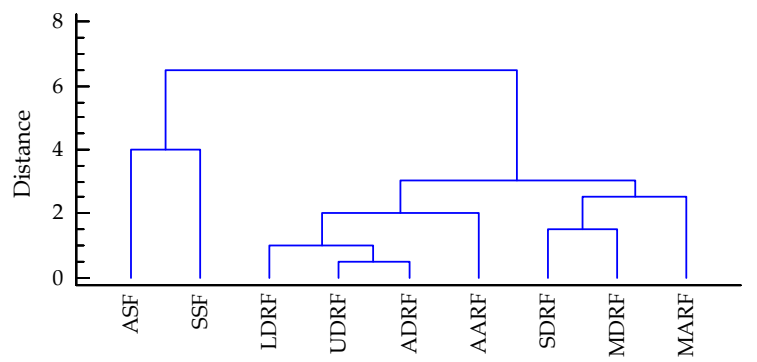

Fig. 6. Dendrogram clustering all Atlantic Forest sites through abundance similarities for tree species with squared euclidean distances and the Ward's method of agglomeration (DRF - Dense Rainforest; ARF - Araucaria Rainforest; SF - Seasonal Forest; A - Alluvial; L - Lowland; S - Submontane; M - Montane; U - Upper Montane). 
The dendrogram based on abundance data (Figure 6) shows some different results as compared with the dendrogram based on the Sorensen's similarity. In the first group are the two Semideciduous Forests, while in the second are all studied Rainforests. This group is divided in two subgroups: one presenting the highest tree species richness and diversities (Shannon-Wiener index) among the rainforests analyzed and other with the lowest richness and diversities.

The first axis resulting from the CCA (eigenvalue $=\lambda=0.637$ ) showed a gradient associated with altitude on one hand and annual temperature an rainfall on the other, separating Montane Rainforests (on the left) and Lowland and Alluvial Rainforests (on the right) (Figure 7). Oliveira-Filho \& Fontes (2000) and Scudeller et al. (2001) found similar patterns for these variables in studies in Southeastern Brazil.

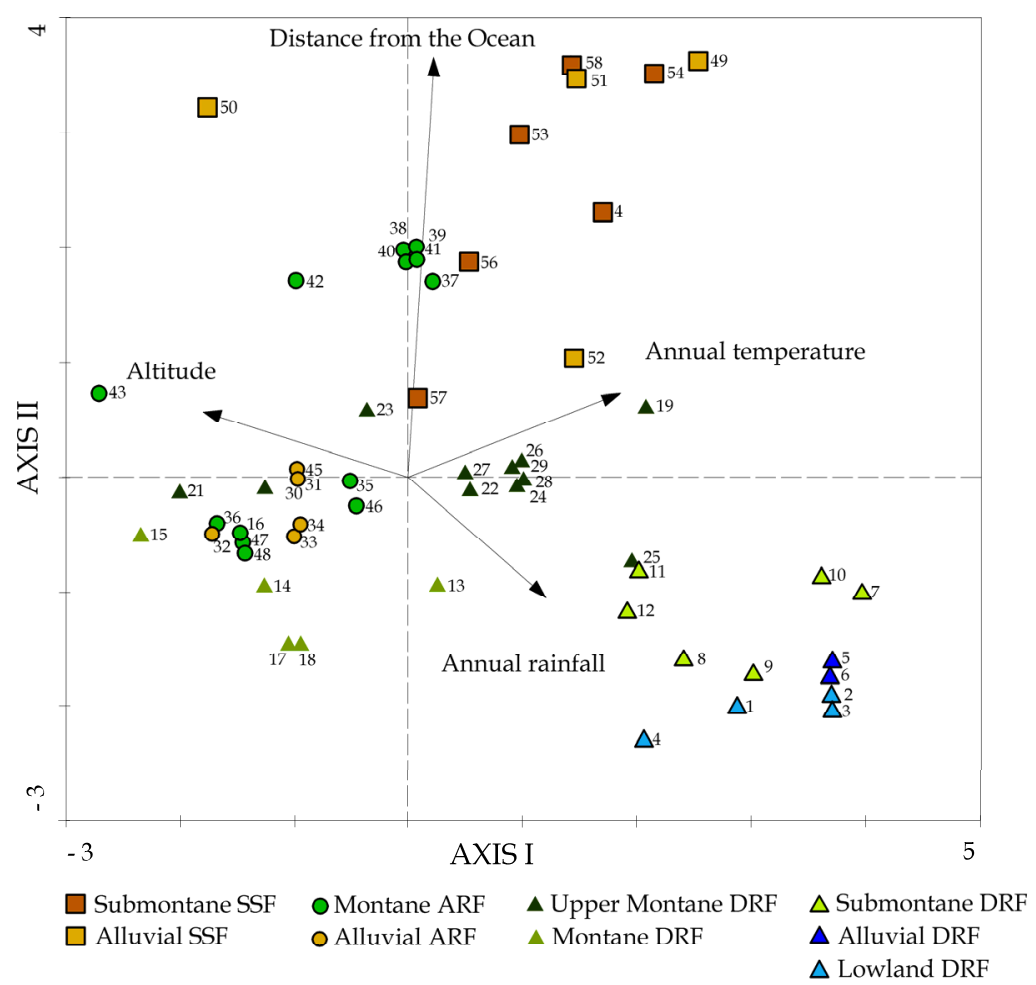

\begin{tabular}{lcccc}
\hline & Axis 1 & Axis 2 & Axis 3 & Axis 4 \\
\hline Eigenvalues (species) & 0.637 & 0.425 & 0.311 & 0.212 \\
$\begin{array}{l}\text { Cumulative percentage variance: } \\
\bullet \quad \text { of species data }\end{array}$ & 4.4 & 7.3 & 9.4 & 10.8 \\
$\quad$ of species-environment relation & 40.2 & 67.0 & 86.7 & 100.0 \\
Species-environment correlations & 0.899 & 0.860 & 0.826 & 0.212 \\
Significance of species-environment correlation (Monte Carlo test) & 0.001 & 0.001 & 0.001 & 0.001 \\
\hline
\end{tabular}

Fig. 7. Biplot of a Canonical Correspondence (CCA) applied to species found in 58 sites in Atlantic Forests in the state of Paraná, Southern Brazil. Numbers are related to sites presented in Table 1. 
The second axis $(\lambda=0.425)$ shows the Semideciduous Seasonal Forest tree species and their abundance change with increasing the distance from the ocean, and decreasing rainfall (and probably increasing rainfall seasonality). The opposite occurred with Submontane, Alluvial and Lowland Dense Rainforests.

The relatively high eigenvalues found $(>0.3)$, indicate considerable abundance and species turnover along gradients mainly in axis 1 and 2. As also found by Scudeller et al. (2001), the low variance explained by the first axis indicates that other variables not investigated or methodological restrictions in this study probably influenced the abundance distribution.

\section{Final considerations}

The literature review and the data compilation resulted in an important database to understand how the Atlantic Forest is being studied in terms of forest structure and tree diversity. The most abundant tree species of this compilation probably corroborate with those found in studies on the Atlantic Forest further South in Brazil (including the state of Santa Catarina), and in Southeastern Brazil (e.g. São Paulo state formations). However, studies analyzing these relationships are needed.

Although many formations are relatively well studied in this respect, some formations such as the alluvial forests, mainly in the Dense Rainforest domain, are understudied. The same situation can be observed for the entire Semideciduous Seasonal Forest. Even more interesting is the lack of phytosociological data about this forest type in the Southwestern region of the state of Paraná. Therefore, future research is needed to build up a database for other and more specific studies. Knowing the species that share (or should share) the environment with ourselves is crucial to those who want to observe the habitat, interpret it and to promote conservation, preservation and true sustainable development.

\section{Acknowledgements}

We would like to thank Kelly Gutseit and Cesar B. Daniel for their valuable comments and suggestions. We are grateful to many colleagues for their substantial help with discussions, support in the office or in the field in some of the our surveys (Alan Y. Mocochinski, Daros A. T. da Silva, Joachim Graf Neto, Juarez Michelotti, Marcelo Brotto, Marília Borgo, Pablo M. Hoffmann, Rafael D. Zenni, Renata C. de Sousa, Ruddy T. Proença, Kelly G. Martins, Franklin Galvão, Carlos V. Roderjan, Otávio A. Bressan and Charles Carneiro).

\section{References}

Athayde, S.F.de. (1997). Composição florística e estrutura fitossociológica em quatro estágios sucessionais de uma Floresta Ombrófila Densa Submontana como subsídio ao manejo ambiental - Guaraqueçaba - PR. M.Sc Dissertation. Pós-graduação em Botânica, Universidade Federal do Paraná. Curitiba, Paraná, Brasil

Barddal, M.L. (2002). Aspectos Florísticos e Fitossociológicos do Componente ArbóreoArbustivo de uma Floresta Ombrófila Mista Aluvial - Araucária, PR. M.Sc Dissertation. Pós-graduação em Engenharia Florestal, Universidade Federal do Paraná. Curitiba, Paraná, Brasil 
Barddal, M.L., Roderjan, C.V., Galvão, F. \& Curcio, G.R. (2004). Caracterização florística e fitossociológica de um trecho sazonalmente inundável de floresta aluvial, em Araucária, PR. Ciência Florestal, Vol. 14, No. 2, ISSN 0103-9954

Bianchini, E., Silveira, R.P., Dias, M.C. \& Pimenta, J.A. (2003). Diversidade e estrutura de espécies arbóreas em área alagável do município de Londrina, sul do Brasil. Acta Botanica Brasilica, Vol. 17, No. 3, pp. 405-419, ISSN 0102-3306

Blum, C.T., Santos, E.P., Hoffmann, P.M. \& Socher, L.G. (2001). Análise Florística e Estrutural de um Trecho de Floresta Ombrófila Densa Montana no Morro dos Perdidos, Serra de Araçatuba, PR. Proceedings of VI Encontro Regional de Botânicos do Paraná e Santa Catarina, Curitiba, november 2001

Blum, C.T., Silva, D.A.T., Hase, L.M. \& Miranda, D.L.C. (2003). Caracterização Florística e Ecológica de Remanescentes Florestais no Rio das Cinzas, Norte Pioneiro/PR. Proceedings of Seminário Nacional Degradação e Recuperação Ambiental - Perspectiva Social, Foz do Iguaçú, november 2003

Blum, C.T. (2006). A Floresta Ombrófila Densa na Serra da Prata, Parque Nacional SaintHilaire/Lange, PR - caracterização florística, fitossociológica e ambiental de um gradiente altitudinal. M.Sc Dissertation. Pós-graduação em Engenharia Florestal, Universidade Federal do Paraná. Curitiba, Paraná, Brasil

Blum, C.T. \& Roderjan, C.V. (2007). Espécies indicadoras em um gradiente da Floresta Ombrófila Densa na Serra da Prata, Paraná, Brasil. Revista Brasileira de Biociências, Vol. 5, No. 2, pp. 873-875, ISSN 1679-2343

Blum, C.T. \& Petean, M.P. (2008). Flora. In: Estudo de Impacto Ambiental da BR-487, trecho Cruzeiro do Oeste - Porto Camargo, PR. ENGEMIN / DNIT, Curitiba.

Blum, C.T. (2010). Os componentes epifítico vascular e herbáceo terrícola da Floresta Ombrófila Densa ao longo de um gradiente altitudinal na Serra da Prata, Paraná. Ph.D Thesis. Pós-graduação em Engenharia Florestal, Universidade Federal do Paraná. Curitiba, Paraná, Brasil

Borghi, W.A., Martins, S.S., Del Quiqui, E.M. \& Nanni, M.R. (2004). Caracterização e avaliação da mata ciliar à montante da hidrelétrica de Rosana, na Estação Ecológica do Caiuá, Diamante do Norte, PR. Cadernos da Biodiversidade, Vol. 4, No. 2, pp. 9-18, ISSN 1415-9112

Campos, J.B., Romagnolo, M.B. \& Souza, M.C. (2000). Structure, composition and spatial distribution and dynamics of tree species in a remnant of Semideciduous Seasonal Alluvial Forest of the Upper Paraná River floodplain. Brazilian Archives of Biology and Technology, Vol. 43, No. 2, pp. 185-194, ISSN 1516-8913

Castella, P.R., Britez, R.M. (2004). A Floresta com Araucária no Paraná: conservação e diagnóstico dos remanescentes florestais, FUPEF/PROBIO/MMA, Brasília

Caviglione, J.H., Kiihl, L.R.B., Caramori, P.H. \& Oliveira, D. (2000). Cartas climáticas do Paraná, IAPAR - Instituto Agronômico do Paraná, Retrieved from: www.iapar.br/modules/conteudo/conteudo.php?conteudo=677

Cordeiro, J. \& Rodrigues, W.A. (2007). Caracterização Fitossociológica de um remanescente de Floresta Ombrófila Mista em Guarapuava, PR. Revista Árvore, Vol. 31, No. 3, pp. 545-554, ISSN 0100-6762

Cordeiro, J. (2010). Compartimentação pedológico-ambiental e sua influência sobre a florística e estrutura de um remanescente de Floresta Ombrófila Mista na região de 
Guarapuava, PR. Ph.D Thesis. Pós-graduação em Engenharia Florestal, Universidade Federal do Paraná. Curitiba, Paraná, Brasil

Costa Filho, L.V., Nanni, M.R. \& Campos, J.B. (2006). Floristic and phytosociological description of a riparian forest and the relationship with the edaphic environment in Caiuá Ecological Station - Paraná - Brazil. Brazilian Archives of Biology and Technology, Vol. 9, No. 5, pp. 785-798, ISSN 1516-8913

Del Quiqui, E.M., Martins, S.S., Silva, I.C., Borghi, W.A., Silva, O. H. da \& Pacheco, R.B. (2007). Estudo fitossosiológico de um trecho da Floresta Estacional Semidecidual em Diamante do Norte, Estado do Paraná, Brasil. Acta Scientiarum, Vol. 29, No. 2, pp. 283-290, ISSN 1679-9275

Durigan, M.E. (1999). Florística, dinâmica e análise protéica de uma Floresta Ombrófila Mista em São João do Triunfo - PR. M.Sc Dissertation. Pós-graduação em Engenharia Florestal, Universidade Federal do Paraná. Curitiba, Paraná, Brasil

Forzza, R.C. et al. (2010). Introdução, In: Lista de Espécies da Flora do Brasil, Acessed april 22, 2011, Available from: <http://floradobrasil.jbrj.gov.br/2010/>

Fundação SOS Mata Atlântica, INPE \& ISA. (1998). Atlas da evolução dos remanescentes florestais da Mata Atlântica e ecossistemas associados período 1990-1995, Fundação SOS Mata Atlântica, São Paulo.

Fundação SOS Mata Atlântica \& INPE (2010). Atlas da evolução dos remanescentes florestais da Mata Atlântica e ecossistemas associados período 2008-2010, Fundação SOS Mata Atlântica, Retrieved from:

http://mapas.sosma.org.br/site_media/download/atlas-relatorio20082010parcial.pdf

Galvão, F., Roderjan, C.V., Ziller, S.R. \& Kuniyoshi, Y.S. (2002). Composição florística e fitossociológica de caxetais do litoral do Estado do Paraná - Brasil. Floresta, Vol. 32, No. 1, pp. 19-42, ISSN 0015-3826

Gentry, A.H. (1995). Patterns of diversity an floristic composition in Neotropical montane forests. In: Biodiversity and conservation of Neotropical montane forests. Neotropical Montane Forest Biodiversity and Conservation Symposium 1, Churchill, S.P., Balslev, H., Forero, E. \& Luteyn. J.L., pp. 103-126, New York Botanical Garden, ISBN 0893274003, New York

Geraldi, S.E., Koehler, A.B. \& Kauano, E.E. (2005). Levantamento Fitossociológico de dois framentos da Floresta Ombrófila Mista em Tijucas do Sul, PR. Revista Acadêmica, Vol. 5, No. 2, pp. 27-36, ISSN 0013-989X

Grubb, P.J. (1971). Interpretation of the "Massenerhebung" effect on tropical mountains. Nature, Vol. 229, pp. 44-45, ISSN 0028-0836

Guapyassú, M.S. (1994). Caracterização fitossociológica de três fases sucessionais de uma Floresta Ombrófila Densa Submontana Morretes - Paraná. M.Sc Dissertation. Pósgraduação em Engenharia Florestal, Universidade Federal do Paraná. Curitiba, Paraná, Brasil

Hueck, K. (1972). As florestas da América do Sul, Polígono, São Paulo.

IBGE (1992). Manual Técnico da Vegetação Brasileira - Manuais Técnicos de Geociências $n^{\circ} 1$, Fundação Instituto Brasileiro de Geografia e Estatística - DERNA, Rio de Janeiro

IPARDES (1986). Algumas Características físicas e cobertura arbórea do Estado do Paraná, CODESUL, Curitiba 
Jaster, C.B. (1995). Análise estrutural de algumas comunidades florestais no litoral do estado do Paraná, na área de domínio da Floresta Ombrófila Densa - Floresta Atlântica. M.Sc Dissertation. Forstwissenschaftlicher Fachbereich, Institut für Waldbau Abteilung II - Tropen und Subtropen, Georg-August-Universität. Göttingen, Deutschland

Jaster, C.B. (2002). A estrutura como indicadora do nível de desenvolvimento sucessional de comunidades arbóreas da restinga - uma proposta metodológica. Ph.D Thesis. Pósgraduação em Engenharia Florestal, Universidade Federal do Paraná. Curitiba, Paraná, Brasil

Jaster, C.B., Iantas, R., Blum, C.T. (2002). Flora. In: Estudo de Impacto Ambiental da Barragem do Rio Miringuava, São José dos Pinhais - PR, SANEPAR - Companhia de Saneamento do Paraná, Curitiba

Klein, R.M. (1979). Ecologia da Flora e Vegetação do Vale do Itajaí. Sellowia - Anais Botânicos do Herbário Barbosa Rodrigues, No. 32

Koehler, A., Galvão \& F., Longhi, S.J. (2002). Floresta Ombrófila Densa Altomontana: aspectos florísticos de diferentes trechos na Serra do Mar, PR. Ciência Florestal, Vol. 12, No. 2, pp. 27-39, ISSN 0103-9954

Kozera, C., Dittrich, V.A.O. \& Silva, S.M. (2006). Fitossociologia do componente arbóreo de um fragmento de Floresta Ombrófila Mista Montana. Floresta, Vol. 36, No. 2, pp. 225-237, ISSN 0015-3826

Lamprecht, H. (1990). Silvicultura nos Trópicos, Deutsche Gesellschaft für Technische Zusammenarbeit - GTZ, ISBN 3-88085-425-4, Eschborn

Laurance, S.G.W., Laurance, W.F., Andrade, A., Fearnside, P.M., Harms, K.E., Vicentini, A. \& Luizao, R.C.C. (2010). Influence of soils and topography on Amazonian tree diversity: a landscape-scale study. Journal of Vegetation Science Vol. 21, pp. 96-106, ISSN 1100-9233

Leite, P.F., Klein, R.M., Pastore, U. \& Coura Neto, A.B. (1986). A vegetação da área de influência do reservatório da usina hidrelétrica de Ilha Grande (PR/MS): levantamento na escala 1:250.000, ELETROSUL - IBGE, Brasília

Leite, P. \& Klein, R.M. (1990). Vegetação. In: Geografia do Brasil: região Sul, Instituto Brasileiro de Geografia e Estatística, pp. 113-150, Rio de Janeiro

Liebsch, D., Goldenberg, R. \& Marques, M.C.M. (2007). Florística e estrutura de comunidades vegetais em uma cronoseqüência de Floresta Atlântica no Estado do Paraná, Brasil. Acta Botanica Brasilica, Vol. 21, No. 4, pp. 983-992, ISSN 0102-3306

Maack, R. (2002). Geografia Física do Estado do Paraná, Imprensa Oficial, Curitiba

Magurran, A.N. (1988). Ecological Diversity and its Measurement, Princeton University Press, ISBN 0-691-08485-8, New Jersey

Melo, M.S., Giannini, P.C.F. \& Pessenda, L.C.R. (2000). Gênese e Evolução da Lagoa Dourada, Ponta Grossa, PR. Revista do Instituto Geológico, Vol. 21, No. 1-2, pp. 17-31, ISSN 0100-929X

Menezes-Silva, S. (1990). Composição florística e fitossociologia de um trecho de floresta de restinga na Ilha do Mel, município de Paranáguá, PR. M.Sc Dissertation. Pósgraduação em Biologia Vegetal, Universidade Estadual de Campinas. Campinas, São Paulo, Brasil 
MINEROPAR (2001). Atlas geológico do Estado do Paraná. Acessed april 22, 2011, Available from: http://www.mineropar.pr.gov.br/arquivos/File/MapasPDF/atlasgeo.pdf

MMA (2011). Mapas de Cobertura Vegetal dos Biomas Brasileiros. Acessed may 06, 2011, Available from

http://mapas.mma.gov.br/mapas/aplic/probio/datadownload.htm

Myers, N., Mittermeier, R.A., Mittermeier, C.G., Fonseca, G.A. \& Kent, J. (2000). Biodiversity hotspots for conservation priorities. Nature, Vol. 403, pp. 853-858, ISSN 0028-0836

Oliveira-Filho, A.T. \& Fontes, M.A.L. (2000). Patterns of Floristic Differentiation among Atlantic Forests in Southeastern Brazil and the Influence of Climate, Biotropica, Vol. 32, No. 4b, pp. 793-810, ISSN 1744-7429

Pasdiora, A.L. (2003). Florística e Fitossociologia de um trecho de Floresta Ripária em dois compartimentos ambientais do rio Iguaçu, Paraná, Brasil. M.Sc Dissertation. Pósgraduação em Engenharia Florestal, Universidade Federal do Paraná. Curitiba, Paraná, Brasil

Pires, P.T.L., Zilli, A.L. \& Blum, C.T. (2005). Atlas da Floresta Atlântica no Paraná - área de abrangência do Programa Proteção da Floresta Atlântica, SEMA/Programa Proteção da Floresta Atlântica - Pró-Atlântica, Curitiba

Pitman, N.C.A, Terborgh, J.W., Silman, M.R., Núñez, P., Neill, D.A., Cerón, C.E., Palacios, W.A. \& Aulestia, M. (2002). A comparison of tree species diversity in two upper Amazonian forests. Ecology, Vol. 83, No. 11, pp. 3210-3224, ISSN 0012-9658

Portes, M.C.G.de O., Galvão, F. \& Koehler, A. (2001). Caracterização florística e estrutural de uma Floresta Ombrófila Densa Altomontana do Morro do Anhangava, Quatro Barras - PR. Floresta, Vol. 31, No, 1/2, pp. 9-18, ISSN 0015-3826

Reginato, M. \& Goldenberg, R. (2007). Análise florística, estrutural e fitogeográfica da vegetação em região de transição entre as Florestas Ombrófilas Mista e Densa Montana, Piraquara, Paraná, Brasil. Hoehnea, Vol. 34, No. 3, pp. 349-364, ISSN 00732877

Ribeiro, M.C., Metzger, J.P., Martensen, A.C., Ponzoni, F.J. \& Hirota, M.M. (2009). The Brazilian Atlantic Forest: How much is left, and how is the remaining forest distributed? Implications for conservation. Biological Conservation Vol. 142, No. 6, pp. 1141-1153, ISSN 0006-3207

Roderjan, C.V. (1994). A Floresta Ombrófila Densa Altomontana do Morro do Anhangava, Quatro Barras, PR - Aspectos climáticos, pedológicos e fitossociológicos. Ph.D Thesis. Pós-graduação em Engenharia Florestal, Universidade Federal do Paraná. Curitiba, Paraná, Brasil

Roderjan, C.V. \& Grodski, L. (1999). Acompanhamento meteorológico em um ambiente de Floresta Ombrófila Densa Altomontana no morro Anhangava, Município de Quatro Barras - PR, no ano de 1993. Cadernos da Biodiversidade, Vol. 2, No. 1, pp. 2734, ISSN 1415-9112

Roderjan, C.V., Galvão, F., Kunizoshi, Y.S. \& Hatschbach, G.G. (2002). As Unidades Fitogeográficas do Estado do Paraná. Ciência \& Meio Ambiente - Fitogeografia do Sul da América, No. 24, pp. 75-92

Rondon Neto, R.M. (2002). Caracterização florística e estrutural de um fragmento de Floresta Ombrófila Mista, em Curitiba, PR - Brasil. Floresta, Vol. 32, No. 1, pp. 3-16, ISSN 0015-3826 
Scheer, M.B. (2010). Ambientes altomontanos no Paraná: florística vascular, estrutura arbórea, relações pedológicas e datações por ${ }^{14} \mathrm{C}$. Ph.D Thesis. Pós-graduação em Engenharia Florestal, Universidade Federal do Paraná. Curitiba, Paraná, Brasil

Scheer, M.B. \& Mocochinski, A.Y. (2009). Floristic composition of four tropical upper montane rain forests in Southern Brazil. Biota Neotropica, Vol. 9, No. 2, pp. 51-70, ISSN 1676-0603 (in portuguese)

Scheer, M.B., Mocochinski, A.Y. \& Roderjan, C.V. (in press a). Tree component structure of tropical upper montane rain forests in Southern Brazil. Acta Botanica Brasilica, ISSN 0102-3306 (in portuguese)

Scheer, M.B., Curcio, G.R. \& Roderjan, C.V. (in press b). Environmental functionalities of upper montane soils in Serra da Igreja, Southern Brazil. Revista Brasileira de Ciência do Solo, ISSN 1806-9657 (in portuguese)

Schorn, L.A. (1992). Levantamento florístico e análise estrutural em três unidades edáficas em uma Floresta Ombrófila Densa Montana no Estado do Paraná. M.Sc Dissertation. Pós-graduação em Engenharia Florestal, Universidade Federal do Paraná. Curitiba, Paraná, Brasil

Scudeller, V.V., Martins, F.R. \& Shepherd, G.J. (2001). Distribution and abundance of arboreal species in the atlantic ombrophilous dense forest in Southeastern Brazil, Plant Ecology, Vol. 152, pp. 185-199, ISSN 1385-0237

Seger, C.D., Dlugosz, F.L., Kurasz, G, Martinez, D.T., Ronconi, E., Melo, L.A.N. de, Bittencourt, S.M. de, Brand, M.A., Carniatto, I., Galvão, F. \& Roderjan, C.V. (2005). Levantamento florístico e análise fitossociológica de um remanescente de Floresta Ombrófila Mista localizado no Município de Pinhais, Paraná - Brasil. Floresta, Vol. 35, No. 2, p. 291-302, ISSN 0015-3826

SEMA (2002). Mapeamento dos Remanescentes de Floresta Estacional Semidecidual, SEMA/FUPEF, Curitiba.

Silva, F.das C. (1994). Composição florística e estrutura fitossociológica da Floresta Tropical Ombrófila da encosta Atlântica no Município de Morretes, Estado do Paraná. Acta Biológica Paranaense, Vol. 23 No. 1-4, pp. 1-54, ISSN: 0301-2123

Silva, F.das C., Fonseca, E.P., Soares-Silva, L.H., Muller, C. \& Bianchini, E. (1995). Composição florística e fitossociologia do componente arbóreo das florestas ciliares da Bacia do Rio Tibagi. 3. Fazenda Bom Sucesso, Município de Sapopema, PR. Acta Botanica Brasilica, Vol. 9, No. 2, pp. 289-302, ISSN 0102-3306

Silva, F.das C. \& Soares-Silva, L.H. (2000). Arboreal flora of the Godoy Forest State Park, Londrina, Pr. Brazil. Edinburgh Journal of Botany, Vol. 57, pp. 107-120, ISSN 09604286

Soares-Silva, L.H., Kita, K.K. \& Silva, F.C. (1998). Fitossociologia de um trecho de floresta de galeria no Parque Estadual Mata dos Godoy, Londrina, PR, Brasil. Boletim do Herbário Ezechias Paulo Heringer Vol. 3, pp. 46-62

Tabarelli, M. \& Mantovani, W. (1999). A riqueza de espécies arbóreas na floresta atlântica de encosta no Estado de São Paulo (Brasil). Revista Brasileira de Botânica, Vol. 22, No. 2, pp. 217-223, ISSN 0100-8404

Ter Braak, C.J.F. \& Smilauer, P. (2002). CANOCO Reference manual and CanoDraw for Windows user's guide: Software for Canonical Community Ordination (version 4.5), Microcomputer Power, Ithaca 
Veiga, M.P. da , Martins, S.S., Silva, I.C., Tormena, C.A. \& Silva, O.H. da. (2003). Avaliação dos aspectos florísticos de uma mata ciliar no Norte do Estado do Paraná. Acta Scientiarum, Maringá, Vol. 25, No. 2, pp. 519-525, ISSN 1679-9275

Veloso, H.P., Rangel Filho, A.L. \& Lima, J.C. (1991). Classificação da Vegetação Brasileira adaptada a um Sistema Universal, Instituto Brasileiro de Geografia e Estatística/Departamento de Recursos Naturais e Estudos Ambientais, Rio de Janeiro

Watzlawick, L.F., Sanquetta, C.R., Valério, A.F. \& Silvestre, R. (2005). Caracterização da composição florística e estrutura de uma Floresta Ombrófila Mista, no Município de General Carneiro (PR). Ambiência, Vol. 1, No. 2, p. 229-237, ISSN 1808-0251

Zacarias, R.R. (2008). O componente arbóreo de dois trechos de Floresta Ombrófila Densa Aluvial em solos hidromórficos, Guaraqueçaba, Paraná. M.Sc Dissertation. Pósgraduação em Ciências Biológicas, Universidade Federal do Paraná. Curitiba, Paraná, Brasil 


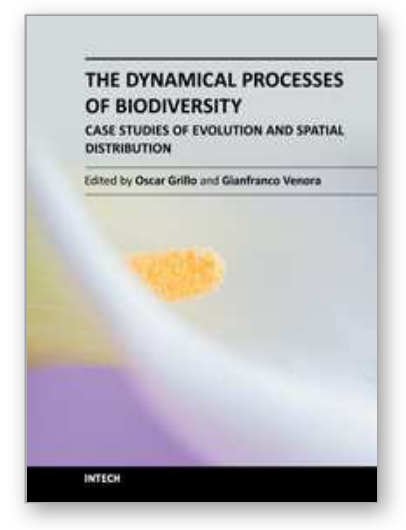

\author{
The Dynamical Processes of Biodiversity - Case Studies of \\ Evolution and Spatial Distribution \\ Edited by PhD. Oscar Grillo
}

ISBN 978-953-307-772-7

Hard cover, 366 pages

Publisher InTech

Published online 02, December, 2011

Published in print edition December, 2011

Driven by the increasing necessity to define the biological diversity frame of widespread, endemic and threatened species, as well as by the stimulating chance to describe new species, the study of the evolutive and spatial dynamics is in constant execution. Systematic overviews, biogeographic and phylogenic backgrounds, species composition and distribution in restricted areas are focal topics of the 15 interesting independent chapters collected in this book, chosen to offer to the reader an overall view of the present condition in which our planet is.

\title{
How to reference
}

In order to correctly reference this scholarly work, feel free to copy and paste the following:

Mauricio Bergamini Scheer and Christopher Thomas Blum (2011). Arboreal Diversity of the Atlantic Forest of Southern Brazil: From the Beach Ridges to the Paraná River, The Dynamical Processes of Biodiversity - Case Studies of Evolution and Spatial Distribution, PhD. Oscar Grillo (Ed.), ISBN: 978-953-307-772-7, InTech, Available from: http://www.intechopen.com/books/the-dynamical-processes-of-biodiversity-case-studies-ofevolution-and-spatial-distribution/arboreal-diversity-of-the-atlantic-forest-of-southern-brazil-from-the-beachridges-to-the-parana-riv

\section{INTECH}

open science | open minds

\section{InTech Europe}

University Campus STeP Ri

Slavka Krautzeka 83/A

51000 Rijeka, Croatia

Phone: +385 (51) 770447

Fax: +385 (51) 686166

www.intechopen.com

\section{InTech China}

Unit 405, Office Block, Hotel Equatorial Shanghai

No.65, Yan An Road (West), Shanghai, 200040, China

中国上海市延安西路65号上海国际贵都大饭店办公楼405单元

Phone: +86-21-62489820

Fax: +86-21-62489821 
(C) 2011 The Author(s). Licensee IntechOpen. This is an open access article distributed under the terms of the Creative Commons Attribution 3.0 License, which permits unrestricted use, distribution, and reproduction in any medium, provided the original work is properly cited. 